\title{
Hanford Prototype Surface Barrier Status Report: FY 1994
}
G. W. Gee
A. L. Ward
H. D. Freeman
S. O. Link
W. H. Walters, Jr.
S. K. Smith.
M. W. Ligotke
B. G. Gilmore
M. D. Campbell
R. A. Romine

December 1994

Prepared for

the U.S. Department of Energy

under Contract DE-AC06-76RLO 1830

Pacific Northwest Laboratory

Richland, Washington 99352 


\section{DISCLAIMER}

This report was prepared as an account of work sponsored by an agency of the United States Government. Neither the United States Government nor any agency thereof, nor any of their employees, make any warranty, express or implied, or assumes any legal liability or responsibility for the accuracy, completeness, or usefulness of any information, apparatus, product, or process disclosed, or represents that its use would not infringe privately owned rights. Reference herein to any specific commercial product, process, or service by trade name, trademark, manufacturer, or otherwise does not necessarily constitute or imply its endorsement, recommendation, or favoring by the United States Government or any agency thereof. The views and opinions of authors expressed herein do not necessarily state or reflect those of the United States Government or any agency thereof. 


\section{DISCLAIMER}

Portions of this document may be illegible in electronic image products. Images are produced from the best available original document. 


\section{Summary}

A full-scale prototype surface barrier has been constructed at the 200 BP-1 Operable Unit in the 200 East Area of the Hanford Site. The prototype barrier has been built to evaluate design, construction, and performance features of a surface barrier that may be used for in-place disposal of wastes at the Hanford Site. The design basis and construction of the prototype have been documented. A testing and monitoring plan has been published outlining specific tests planned for the prototype. The current report describes initial testing activities conducted in FY 1994 and outlines activities for testing and monitoring at the prototype barrier in the future.

Asphalt permeability was tested during construction of the prototype in April and May 1994. Cores taken from the asphalt concrete layer were tested in the laboratory and found to have hydraulic conductivities below $1 E-09 \mathrm{~cm} / \mathrm{s}$. Field measurements of hydraulic conductivity taken on the asphalt concrete using a specially-designed falling head permeameter were more than ten times higher than those from core tests. The higher values are attributed to transient flow through the permeameter seal. In spite of this difficulty, the more rapid field measurements (1-day tests in the field compared to 3 months in the laboratory) gave values as low as $1 \mathrm{E}-09 \mathrm{~cm} / \mathrm{s}$ and averaged about $1 \mathrm{E}-08 \mathrm{~cm} / \mathrm{s}$. Samples of fluid-applied asphalt material, used as a sealant on the asphalt concrete layer, were tested in the laboratory and found to have hydraulic conductivities below $1 \mathrm{E}-10 \mathrm{~cm} / \mathrm{s}$. Measurements of hydraulic conductivity taken on an adjacent asphalt test pad using a sealed double-ring infiltrometer (SDRI) were initiated in September 1994 and are expected to be completed in November 1994.

Construction of the prototype surface barrier was completed in August 1994. The soil surface was smoothed to eliminate excessive ridges and furrows left after final soil spreading was completed. Wind erosion equipment, including anemometers and saltation samplers were installed, and initial wind erosion measurements were taken in late August and early September before the surface was irrigated. Initial pea-gravel composition of the surface soil ranged from 12 to $15 \mathrm{wt} \%$ and averaged $14 \%$ over the entire surface. The composition of the surface layer will be monitored over time to assess surface soil losses. Soil water contents ranged from near zero at the surface to about $6 \mathrm{wt} \%$ at depths below $0.2 \mathrm{~m}$. Soil bulk density ranged from 1.2 to $1.6 \mathrm{~g} / \mathrm{cc}$. Wind gusts in early September caused small but measurable soil losses from very loose, dry surfaces.

A grid system was placed on the soil surface in September. Marked stakes were placed on 3-m centers in the soil surface, and the grid system was surveyed allowing for exact placement of instrumentation and sampling stations. A water erosion flume and associated monitoring equipment were installed on the south end of the prototype barrier in September. Creep gauges were installed along the rock side slope and subsequently surveyed to document side slope stability. Periodic surveys of these creep gauges are planned.

In September 1994, the soil surface of the prototype was irrigated. Approximately $120 \mathrm{~mm}$ of water was applied to the surface, and the soil profile was wetted to a depth of about $1 \mathrm{~m}$. Water 
storage increased substantially, and there was a general settlement in the soil surface of about $10 \mathrm{~cm}$ as a result of the irrigation. Water balance monitoring stations were established on the soil surface. A survey of the soil surface was made using electromagnetic induction meters, which measure effective electrical conductivity of the soil profile and can be calibrated to measure soil water content and water storage.

Water drainage monitoring stations were instrumented with tipping buckets, thermocouples, pressure transducers, and electronic float valves, and the instrumentation was connected to data logging equipment. These drainage stations allow for precise and continuous measuring of drainage during testing. The expected error in drainage measurements is estimated to be $<0.05 \mathrm{~mm}$. Waterline and power are expected to be installed in October 1994. The surface will be revegetated in early November. Extensive testing and monitoring of the prototype is scheduled to begin in November 1994, and to continue for 3 years. 


\section{Acknowledgments}

We wish to thank the Hanford Barrier Design Team, consisting of staff from Kaiser Engineers Hanford (KEH), Westinghouse Hanford Company (WHC), Pacific Northwest Laboratory (PNL), Bechtel Hanford Incorporated (BHI), and IT Hanford Incorporated (IT), for persisting in the design and subsequent construction of the prototype barrier and in assisting in development of plans to test and monitor the prototype. Special thanks go to Dave Fort, who directed the prototype design work; Dick Wing, who has been the cognizant engineer for the Hanford Protective Barrier Development program for many years; and Mark Buckmaster, who guided the construction of the prototype to its successful conclusion. We also wish to thank support staff Jason Ritter, Rod Davis, Ray Clayton, Gary Dennis, and Owen Abbey who ably assisted in the installation of test equipment. Funding for the development of permanent isolation barriers and the prototype has been provided by the U.S. Department of Energy's Environmental Restoration (ER) Program under Contract DE-AC06-76RLO 1830. 
. 


\section{Contents}

Summary $\ldots \ldots \ldots \ldots \ldots \ldots \ldots \ldots \ldots \ldots \ldots \ldots \ldots \ldots \ldots \ldots$

Acknowledgments $\ldots \ldots \ldots \ldots \ldots \ldots \ldots \ldots \ldots \ldots \ldots \ldots \ldots \ldots$

1.0 Introduction $\ldots \ldots \ldots \ldots \ldots \ldots \ldots \ldots \ldots \ldots \ldots \ldots \ldots \ldots \ldots \ldots \ldots \ldots$

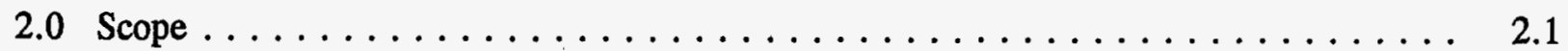

2.1 Construction of the Prototype Barrier $\ldots \ldots \ldots \ldots \ldots \ldots \ldots \ldots \ldots \ldots$

2.2 Prototype Testing and Performance Monitoring . . . . . . . . . . 2.2

3.0 Prototype Barrier Testing and Monitoring Activities $\ldots \ldots \ldots \ldots \ldots \ldots \ldots$

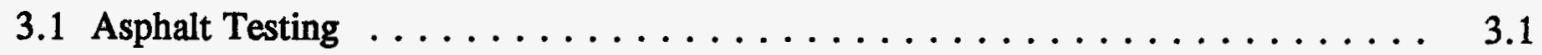

3.1.1 Hydraulic Conductivity $\ldots \ldots \ldots \ldots \ldots \ldots \ldots \ldots \ldots \ldots \ldots \ldots$

3.1.2 Asphalt Test Pad Monitoring $\ldots \ldots \ldots \ldots \ldots \ldots \ldots \ldots \ldots$

3.1 .3 Summary $\ldots \ldots \ldots \ldots \ldots \ldots \ldots \ldots \ldots \ldots \ldots \ldots \ldots$

3.2 Wind Erosion Monitoring Task $\ldots \ldots \ldots \ldots \ldots \ldots \ldots \ldots \ldots \ldots \ldots \ldots$

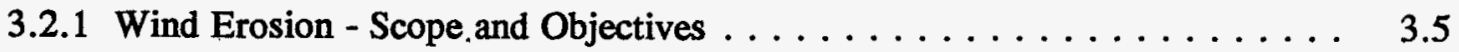

3.2.2 Wind Erosion Testing and Monitoring Activities . . . . . . . . 3.6

3.2.3 Wind Erosion - Conclusions and Recommendations . . . . . . . . . . 3.9

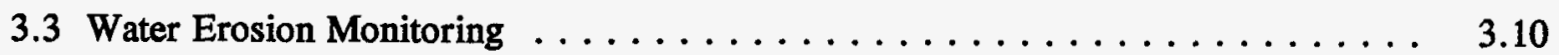

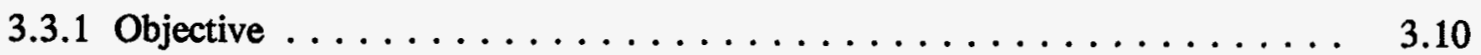

3.3 .2 Monitoring Approach $\ldots \ldots \ldots \ldots \ldots \ldots \ldots \ldots \ldots \ldots \ldots$

3.3.3 Expected Results $\ldots \ldots \ldots \ldots \ldots \ldots \ldots \ldots \ldots \ldots \ldots \ldots \ldots \ldots . \ldots \ldots$

3.3.4 Controlled Area Monitoring $\ldots \ldots \ldots \ldots \ldots \ldots \ldots \ldots \ldots \ldots \ldots . \ldots \ldots$

3.3.5 Expected Results $\ldots \ldots \ldots \ldots \ldots \ldots \ldots \ldots \ldots \ldots \ldots \ldots \ldots \ldots . \ldots \ldots$ 
3.4 Water Balance Tests $\ldots \ldots \ldots \ldots \ldots \ldots \ldots \ldots \ldots \ldots \ldots \ldots \ldots$

3.4.1 Water Balance Scope and Objectives $\ldots \ldots \ldots \ldots \ldots \ldots \ldots . \ldots \ldots$

3.4.2 Water Application and Measurement $\ldots \ldots \ldots \ldots \ldots \ldots \ldots \ldots$

3.4.3 Water Content and Water Storage Measurement $\ldots \ldots \ldots \ldots \ldots \ldots . . \ldots$

3.4.4 Drainage Measurements $\ldots \ldots \ldots \ldots \ldots \ldots \ldots \ldots \ldots \ldots$

3.4.5 Other Measurements $\ldots \ldots \ldots \ldots \ldots \ldots \ldots \ldots \ldots \ldots \ldots . \ldots \ldots$

3.4 .6 Summary $\ldots \ldots \ldots \ldots \ldots \ldots \ldots \ldots \ldots \ldots \ldots \ldots \ldots \ldots$

3.5 Biointrusion $\ldots \ldots \ldots \ldots \ldots \ldots \ldots \ldots \ldots \ldots \ldots \ldots \ldots \ldots \ldots$

3.5.1 Vegetation Establishment and Monitoring $\ldots \ldots \ldots \ldots \ldots \ldots \ldots$

3.5.2 Root Intrusion/Root Distribution . . . . . . . . . . . . . . 3.19

3.5.3 Animal Intrusion Subtask . . . . . . . . . . . . . . . . 3.19

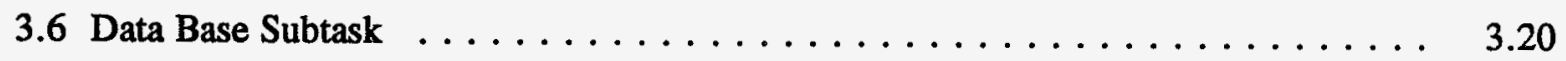

3.6.1 Data Base Strategy . . . . . . . . . . . . . . . . . 3.20

3.6.2 Repository for Data Base . . . . . . . . . . . . . . . 3.20

3.6.3 Selection of Data Base $\ldots \ldots \ldots \ldots \ldots \ldots \ldots \ldots \ldots \ldots \ldots$

3.6.4 Data Base . . . . . . . . . . . . . . . . . . 3.21

3.6.5 Relational Scheme $\ldots \ldots \ldots \ldots \ldots \ldots \ldots \ldots \ldots \ldots \ldots . \ldots \ldots$. . . . . . . . . .

4.0 Future Plans and Activities $\ldots \ldots \ldots \ldots \ldots \ldots \ldots \ldots \ldots \ldots \ldots \ldots \ldots$

5.0 References $\ldots \ldots \ldots \ldots \ldots \ldots \ldots \ldots \ldots \ldots \ldots \ldots \ldots \ldots \ldots \ldots \ldots$

Appendix - Water Balance Equipment at the Prototype Site . . . . . . . . . . . . . A.1 


\section{Figures}

1.1 Completed Prototype Barrier at the 200-BP-1 Operable Unit, 200 East Area of the Hanford Site, Washington . . . . . . . . . . . . . 1.2

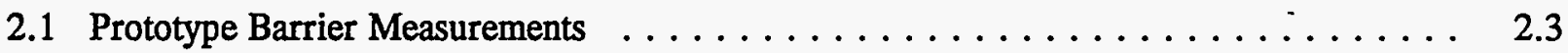

2.2 Surface Instrumentation Layout at the Prototype Barrier $\ldots \ldots \ldots \ldots \ldots$

3.1 In-Place Falling Head Permeameter for Asphalt Field

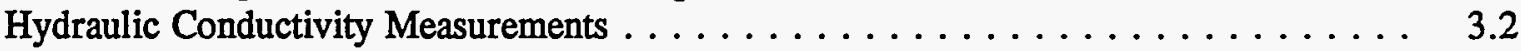

3.2 Rock Creep Gauge for Basalt Side Slope Stability Test $\ldots \ldots \ldots \ldots \ldots \ldots$

3.3 An Example Entity Relationship Diagram for Wind Erosion Data . . . . . . . . . . 3.23

\section{Tables}

3.1 Hydraulic Conductivity of the HMAC Layer of the Prototype Barrier . . . . . . . . 3.3

3.2 Summary of Hydraulic Conductivity Data for Prototype HMAC Cores . . . . . . . . 3.4

3.3 Hydraulic Conductivity of Polymer-Modified Asphalt Membrane

Samples from the Prototype Barrier $\ldots \ldots \ldots \ldots \ldots \ldots \ldots \ldots \ldots \ldots \ldots$ 


\subsection{Introduction}

The exhumation and treatment of wastes may not always be the preferred alternative in the remediation of a waste site. In-place disposal alternatives ultimately may be the most desirable to protect human health and the environment. The implementation of an in-place disposal alternative will likely require some type of protective covering that will provide long-term isolation of the wastes from the accessible environment. (Even if the wastes are exhumed and treated, a long-term barrier may still be needed to adequately dispose of the wastes.) Currently, no "proven" long-term barrier system is available. The Hanford Site Permanent Isolation Surface Barrier Development Program (BDP) was organized to develop the technology needed to provide a long-term surface barrier capability for the Hanford Site.

The objective of the current barrier design is to use natural materials to develop a protective barrier system that isolates wastes for at least 1000 years by limiting water, plant, animal and human intrusion, and minimizing erosion. The design criteria for water drainage has been set at $0.5 \mathrm{~mm} / \mathrm{yr}$ (Myers and Duranceau 1994). Other isolation criteria are less quantitative.

Extensive work has been done at the Hanford Site to develop surface barrier technology. A BDP initiated in 1985 has continued to develop and test barrier concepts designed to meet Hanford Site cleanup needs. The Barrier Development Plan (Wing 1994) has been the baseline planning document for the development of protective barrier systems on the Hanford Site. The plan identifies, describes, and logically relates the tasks that are required to resolve the technical concerns regarding protective barrier systems. The plan was intended to provide information regarding technical developments, cost estimates, and scheduled completion dates of barrier and marker development tasks. The plan provides general direction to, and integration of, all Hanford Site barrier studies. This program has, in sequential steps, led to the construction of a prototype barrier over an operable unit (200-BP-1) at the Hanford Site (Figure 1.1).

The results of development and testing efforts conducted so far are not final; however, enough data existed to allow the design and construction of a prototype. A design basis document (Myers and Duranceau 1994) provides the rationale for the design features of the prototype, and a construction report (DOE 1994) details the construction features and costs associated with the prototype barrier. The full-scale prototype surface barrier will allow engineers and scientists to gain insights into, and experience with, issues regarding barrier design, construction, and performance that have not been possible with the individual tests and experiments conducted to date in the program (Wing and Gee 1994).

This report provides a status of the testing and monitoring activities for the prototype barrier. Section 2.0 of the report reviews the present scope of the testing and monitoring activities. Section 3.0 documents the initial testing of the asphalt layer; the installation of wind and water erosion equipment, 


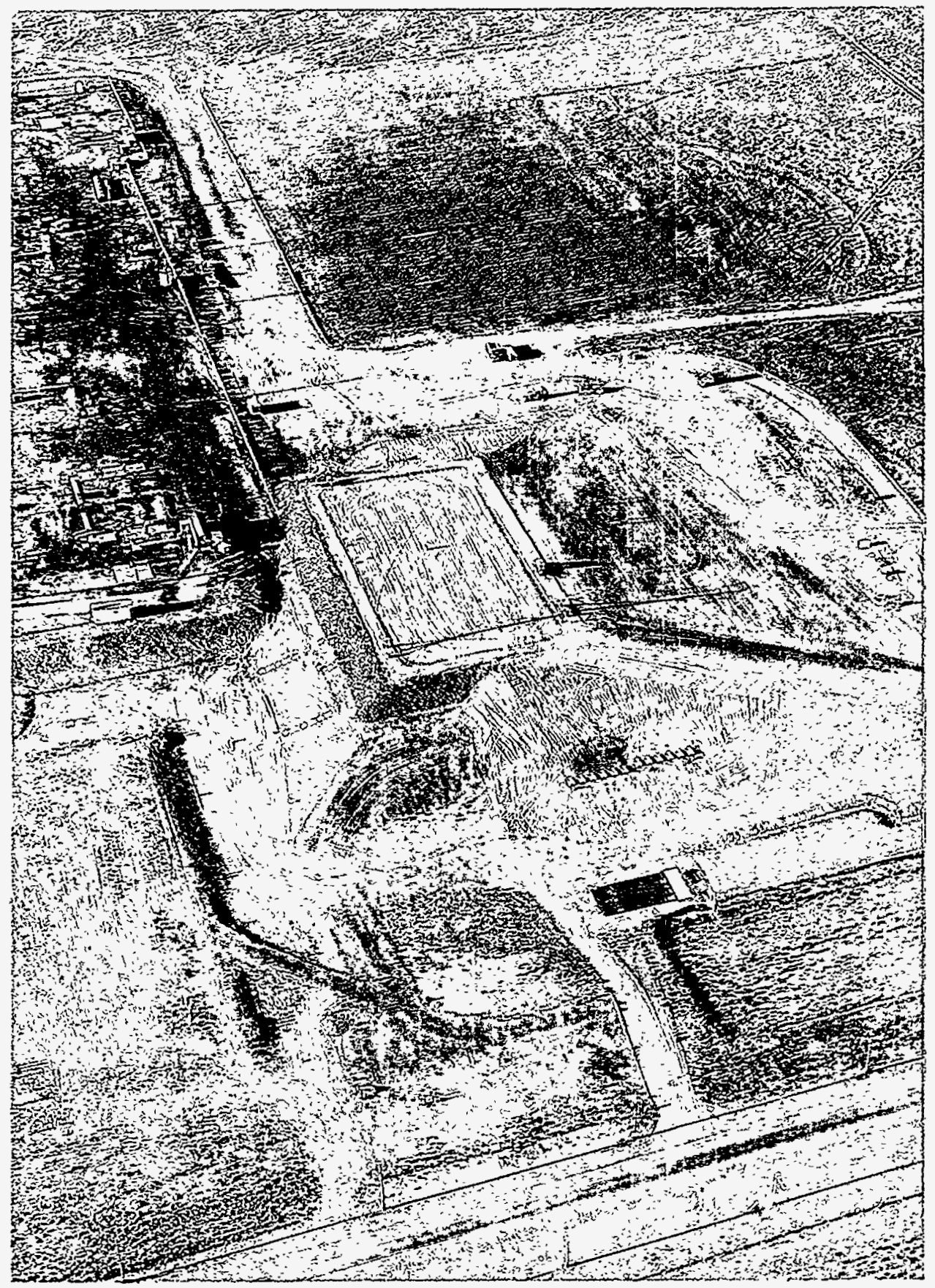

Figure 1.1. Completed Prototype Barrier at the 200-BP-1 Operable Unit, 200 East Area of the Hanford Site, Washington 
settlement gauges, and surface markers; the installation of water balance equipment; the revegetation and biointrusion activities and plans; and the development of a common data base structure for all prototype barrier activities. Section 4.0 discusses future plans and recommended activities for the prototype barrier and the surface barrier program at the Hanford Site. 


\subsection{Scope}

Testing and monitoring of the prototype surface barrier's performance will be required for at least 3 years following construction. Approximately 1 year is expected to be required for the prototype surface barrier to stabilize after construction is completed, instruments are installed, and experiments are initiated. Once the prototype stabilizes, a minimum of 2 years of testing and performance monitoring will be required. During that time, measurement of water infiltration and redistribution and drainage from all components of the barrier, including the side slopes and subsurface asphalt layers, will quantify barrier performance in isolating waste from meteoric water sources both under ambient and increased precipitation conditions. Effects of wind and water erosion, as well as biointrusion, will also be documented carefully. Details of the required testing and monitoring of the prototype are provided in the following sections of this report. Continued monitoring of prototype surface barrier performance over extended periods of time is desirable but will be subject to the availability of funding as well as to the types of monitoring techniques used (i.e., destructive sampling). Additional performance data would provide increased confidence in long-term predictions of barrier stability and performance.

\subsection{Construction of the Prototype Barrier}

The prototype barrier was constructed on the 200 Area Plateau at the 200-BP-1 Operable Unit. This Operable Unit (a designation for major cleanup areas at the Hanford Site) is located in the northwest quadrant of the 200 East Area. A detailed description of this site is provided in a report by Kaiser Engineers Hanford (KEH 1993). The prototype barrier is located over the B-57 Crib. A complete description of the siting of the barrier is also given by $\mathrm{KEH}$ (1993) and the construction of the prototype has been documented (DOE 1994).

The prototype was designed to represent a cover that has two distinct side slopes. One side slope is a relatively steep (2:1 horizontal to vertical) basalt rip-rap, while the other side slope is "clean fill" material (consisting of local gravel/sand backfill) at a shallow (10:1) slope. The plan view of the prototype (Figure 1.1) shows an area of approximately $6000 \mathrm{~m}^{2}$ for the test sections. This area is underlain by a composite asphalt layer that is divided into a series of lysimeter pads leading to collectors, which will be monitored over the course of the testing and monitoring period. Confirmation of the low permeability of the asphalt layer was made in three ways. First, cores taken from the north end of the prototype were tested in the laboratory for hydraulic conductivity (permeability). Second, a test pad of composite asphalt layer was constructed coincident with the construction of the prototype asphalt layer (but adjacent to the prototype). The pad is currently being tested for hydraulic conductivity, and by inference the asphalt layer conductivity will be determined. Third, a geomembrane-type pan lysimeter was constructed on the northeast section of the prototype. This lysimeter ensures collection of all water that may seep through the asphalt layer. The pan lysimeter was placed under a section of the asphalt that is located below the coarse (basalt rock) side slope where 
maximum water infiltration is expected. The as-built drawings showing the asphalt layer structure, the diversion channels, and the collection system for all of the barrier are provided by DOE (1994).

\subsection{Prototype Testing and Performance Monitoring}

The prototype surface barrier will be tested and monitored to evaluate its performance over a range of conditions. A series of tests and experiments will be conducted on the prototype surface barrier to assess its performance with respect to water infiltration, biointrusion, erosion, and physical stability. Figure 2.1 lists the types of measurements that will be made on the prototype barrier and Figure 2.2 shows the location of the measurements stations that have been established on the prototype. Because there is only a relatively short time to test a prototype barrier that is intended to function for 1000 years or more, the testing program will be designed to "stress" the prototype so that barrier performance can be determined within a reasonable time (see Wing and Gee 1994 and Figure 1.1). Stress on the barrier will be induced by applications of water that will simulate 1000 -year storm events and produce a total water application of three times the average annual precipitation.

Following prototype construction, it is expected to take about 1 year for the prototype to stabilize. During this year, the soil in the prototype surface barrier may experience a small but measurable amount of settlement. (Because the barrier is located over a stable crib with an extremely stable coarse sand and gravel subbase, significant differential settlement or subsidence is not expected to occur.) The actual amount of settlement will be fully documented. In addition, the moisture contents of the soils are expected to adjust from construction levels to more natural field conditions, and vegetation is expected to become established on the barrier surface. Once the prototype barrier has stabilized, there will be a baseline from which test data on prototype performance can be collected. Performance data on water redistribution, drainage, erosion, stability, and intrusion by plants and animals should then be collected over a minimum of two complete growing cycles (fall and winter rainfall seasons, and spring and summer growing seasons). Thus, a minimum of 3 years of rigorous monitoring and analysis of test data is required.

Other processes that will affect a protective barrier will occur over a longer period of time. These processes include (but are not limited to) succession of vegetation types, full development of root profiles, and natural colonization of the barrier surface by burrowing animals. Consequently, it is desirable to maintain a reduced level of monitoring beyond the 3-year period of rigorous monitoring. Funding will be sought to maintain the prototype as a long-term monitoring facility because it should prove to be invaluable in hydrologic model validation studies and in the assessment of the long-term performance of cover systems at the Hanford Site.

It is anticipated that the success of the prototype tests will determine the ultimate successful use of surface barriers for waste isolation at the Hanford Site. 
Prototype Barrier Measurements

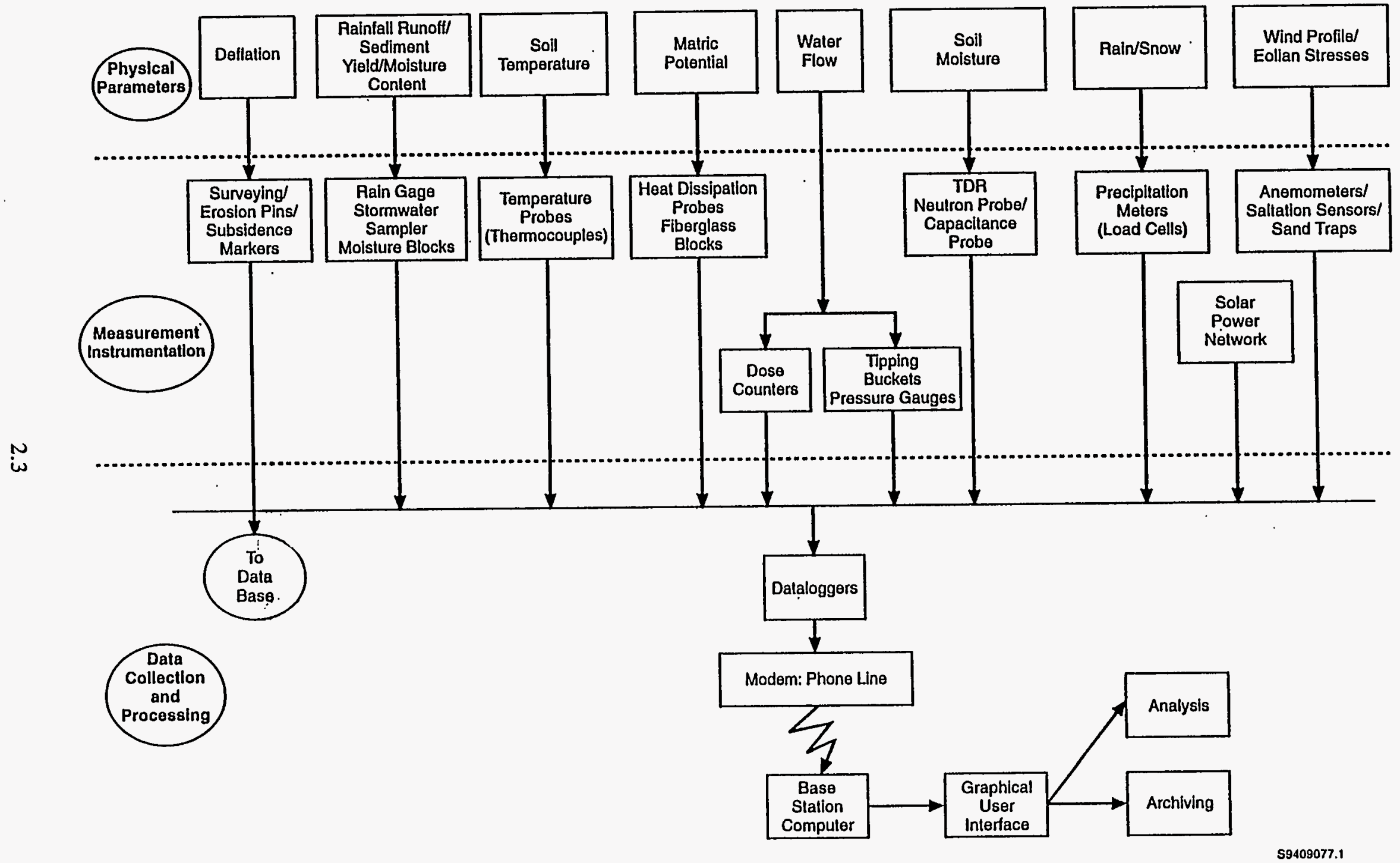

Figure 2.1. Prototype Barrier Measurements 


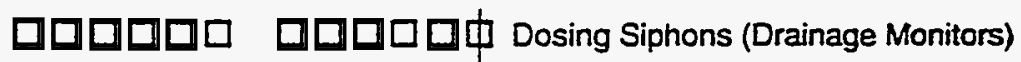

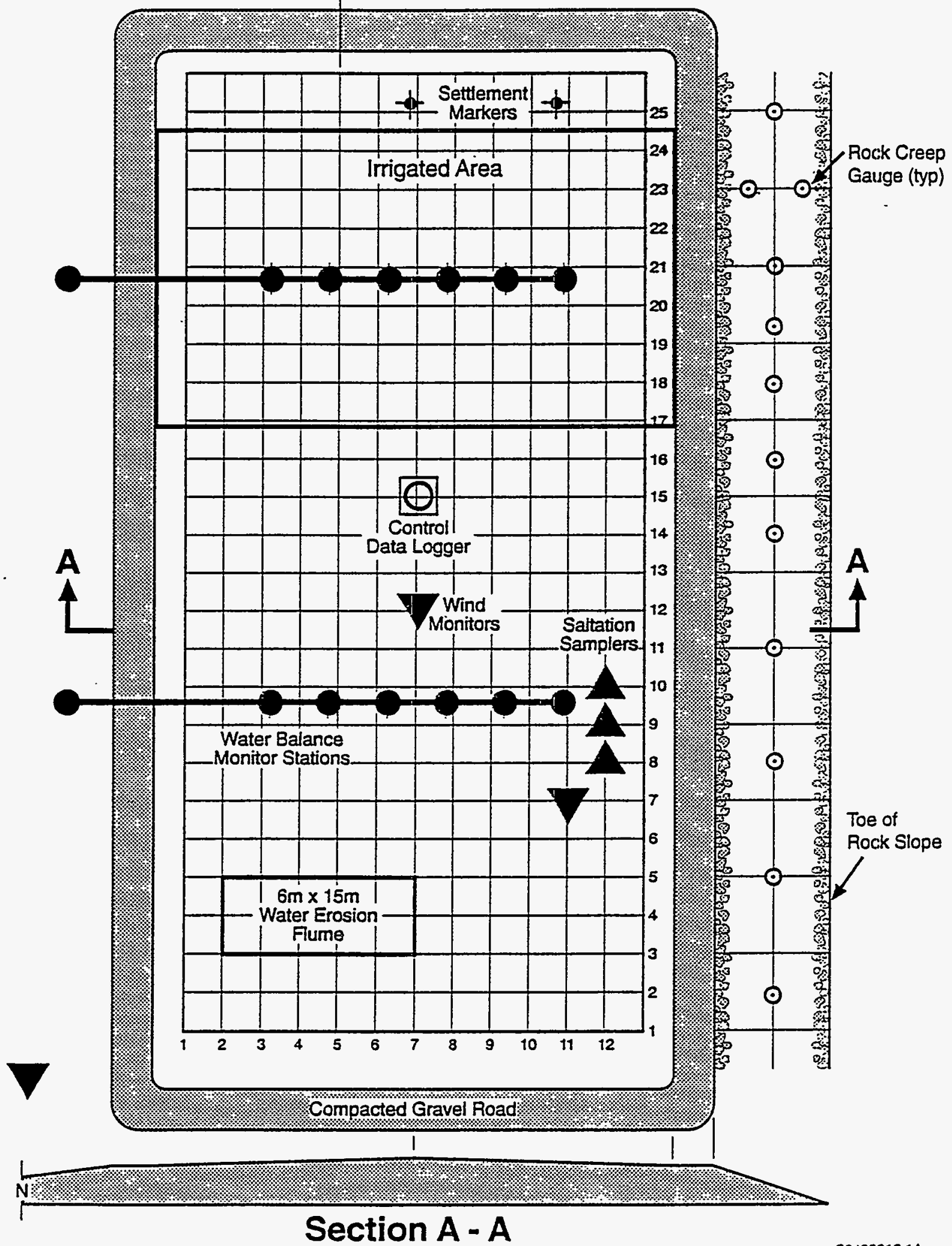

Figure 2.2. Surface Instrumentation Layout at the Prototype Barrier 


\subsection{Prototype Barrier Testing and Monitoring Activities}

A number of tests and experiments will be conducted on the prototype barrier to assess the prototype's performance including physical stability, erosion, biointrusion, and water infiltration. During FY 1994, construction delays until the end of August prolonged the installation of equipment throughout the month of September. However, some preliminary testing was initiated and plans for future testing were drafted. The following sections describe these efforts.

\subsection{Asphalt Testing}

The asphalt layer within the Hanford Permanent Isolation Barrier (HPIB) is an important component of the overall design. This layer provides a RCRA equivalent backup to the overlying earthen layers in the unlikely event that these layers are not able to reduce the infiltration rate to less than $0.5 \mathrm{~mm} / \mathrm{yr}$. There is only limited information on using asphalt for a moisture infiltration barrier. Therefore, a number of activities are under way, as part of the Barrier Development Program (BDP), to obtain data on the performance of asphalt as a moisture barrier in a buried environment over a 1000-year period. These activities include: 1) determining RCRA equivalency, 2) measuring physical properties, 3) measuring aging characteristics, and 4) evaluating ancient asphalt analogs. Progress has been made on all of these activities. We report here studies that were conducted both in the laboratory and on the prototype barrier in April 1994, after the asphalt layer was placed on the backfill materials.

\subsubsection{Hydraulic Conductivity}

Measurements of the hot-mixed asphalt concrete (HMAC) layer of the prototype barrier were made in the field and also on cones removed from the prototype and taken to the laboratory.

\subsubsection{Field Tests}

Field hydraulic conductivity measurements were made using a specially constructed in-place (field) falling head permeameter (FFHP). The permeameter shown in Figure 3.1 measures an area of $\sim 0.05 \mathrm{~m}^{2}$ and is constructed of a stainless steel confining ring and acrylic top and stand tube. The permeameter is sealed into a groove cut 5 to $10 \mathrm{~cm}$ deep and sealed with pure bentonite or bentonite grout. The water head used in the measurement is controlled by the height of water placed in the stand tube. The water head used in these measurements was approximately $2 \mathrm{~m}$, which is more than a factor of two above that used in a normal sealed double-ring infiltrometer (SDRI) test. A major advantage over SDRI techniques is that the FFHP permeameters can be easily transported and setup by one person. The measurements taken with the FFHP device are conservatively high because they are shortterm ( 1 day) measurements and reflect a transient wetting of the asphalt and the grout seal. 


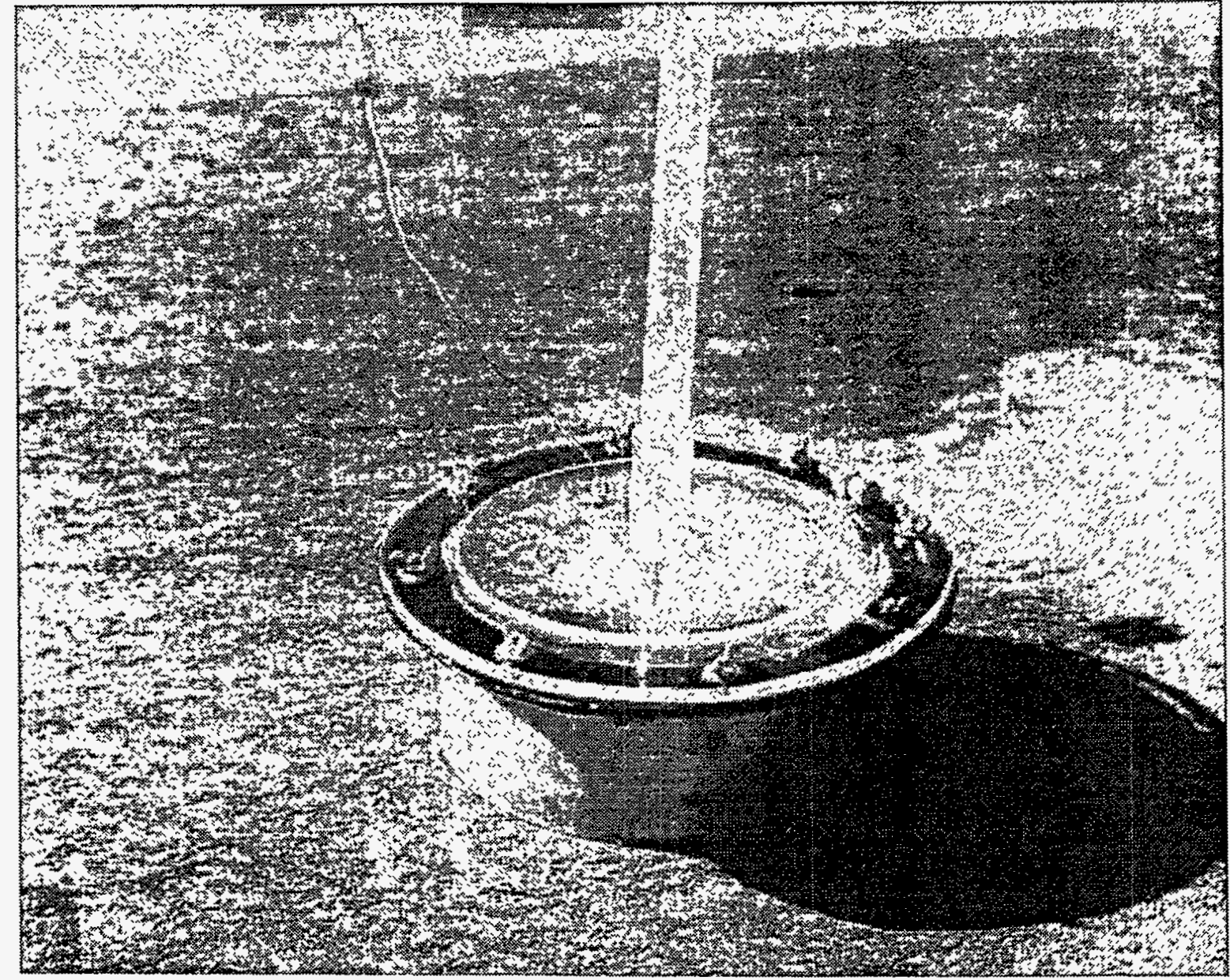

Figure 3.1. In-Place Falling Head Permeameter for Asphalt

Field Hydraulic Conductivity Measurements

Preliminary tests indicated that the most stable readings occur after the grout seal is allowed to wet for at least 24 hours. The FFHP provided a rapid means to check hydraulic conductivity on numerous locations (including seams) on the asphalt surface.

Results of the FFHP measurements made at the north end of the prototype barrier are given in Table 3.1. These data show that the hydraulic conductivity at location 2 was greatest. This was because the measurement was made directly on a surface seam. Because the confining rings did not completely penetrate through the top lift of asphalt, there was a path for water movement under the confining ring that resulted in higher hydraulic conductivity. This measurement was most likely invalid because hydraulic conductivity was not measured through both layers of the HMAC. These results demonstrate the need to ensure that test grooves and the confining ring of the permeameters are made deep enough to penetrate completely through the top layer of the HMAC. In spite of this deficiency, the seam conductivity was very close to $1.0 \mathrm{E}-7 \mathrm{~cm} / \mathrm{s}$ and all other measurements averaged well below $1.0 \mathrm{E}-7 \mathrm{~cm} / \mathrm{s}$. 
Table 3.1. Hydraulic Conductivity of the HMAC Layer of the Prototype Barrier $(\mathrm{cm} / \mathrm{s})$

\begin{tabular}{|c|c|c|c|c|c||}
\hline \hline Location & 27 Apr & 28 Apr & 29 Apr & 30 Apr & 1 May \\
\hline \hline 1 & - & - & $3.09 \mathrm{E}-08$ & $3.88 \mathrm{E}-08$ & $1.91 \mathrm{E}-09$ \\
\hline 2 & - & - & $3.92 \mathrm{E}-07$ & $2.16 \mathrm{E}-07$ & $1.08 \mathrm{E}-07$ \\
\hline 3 & $1.05 \mathrm{E}-07$ & $3.06 \mathrm{E}-08$ & $2.09 \mathrm{E}-08$ & $5.66 \mathrm{E}-09$ & $1.47 \mathrm{E}-08$ \\
\hline 4 & -- & $9.27 \mathrm{E}-08$ & $9.69 \mathrm{E}-08$ & - & $4.33 \mathrm{E}-08$ \\
\hline 5 & - & $5.44 \mathrm{E}-08$ & $2.80 \mathrm{E}-08$ & $1.43 \mathrm{E}-08$ & $1.51 \mathrm{E}-08$ \\
\hline
\end{tabular}

\subsubsection{Laboratory Tests}

For later use in laboratory hydraulic conductivity measurements, twelve core samples were taken at six locations (two per location) at the north end of the prototype barrier. Five of these cores were selected for testing while the remainder were reserved for later tests. Measurements were made using standard laboratory falling head measurement techniques using a $2.5-\mathrm{m}$ head of water. Daily measurements were made by noting the height of water in a 5-ml pipette attached to the top of each test setup. Tests were carried out for over 3 weeks, and hydraulic conductivity was calculated based on the change in volume over the 3-week period (Table 3.2). Overall, the cores averaged $4.69 \times 10^{-10} \mathrm{~cm} / \mathrm{s}$. The difference between field and core (laboratory) tests is because the field technique uses several conservative assumptions that result in a higher-than-actual hydraulic conductivity.

Hydraulic conductivity measurements on samples taken from the prototype barrier during installation of the fluid applied asphalt (FAA) were made using the same techniques as described for the prototype core samples.

Measurements made on the FAA membrane (polymer-modified asphalt) (Table 3.3) show an extremely low permeability of less than $1.0 \mathrm{E}-10 \mathrm{~cm} / \mathrm{s}$. This confirms that the combination of HMAC and FAA will likely exceed regulatory criteria by several orders of magnitude, and it will also exceed the design objective of $0.5 \mathrm{~mm} / \mathrm{yr}(1.6 \mathrm{E}-09 \mathrm{~cm} / \mathrm{s})$ by nearly two orders of magnitude. Using FAA as a surface coating on the HMAC should prevent surface seams in the HMAC from compromising the overall performance of the asphalt barrier.

\subsubsection{Asphalt Test Pad Monitoring}

SDRI tests are currently under way on the asphalt test pad north of the prototype barrier to determine the hydraulic conductivity of a seamed and unseamed area. The SDRI tests will give data on hydraulic conductivity of larger areas of the HMAC without the bias of lateral flow of water from the 
Table 3.2. Summary of Hydraulic Conductivity Data for Prototype HMAC Cores

\begin{tabular}{||c|c|c||}
\hline \hline Sample & Thickness $(\mathrm{cm})$ & Hydraulic Conductivity $(\mathrm{cm} / \mathrm{s})$ \\
\hline \hline 1A & 15.3 & $1.32 \mathrm{E}-09$ \\
\hline 2A & 14.8 & $3.45 \mathrm{E}-10$ \\
\hline $3 \mathrm{~A}$ & 16.7 & $2.42 \mathrm{E}-10$ \\
\hline 4A & 17.1 & $1.24 \mathrm{E}-10$ \\
\hline 5A & 14.1 & $3.16 \mathrm{E}-10$ \\
\hline \hline Average & 15.6 & $4.69 \mathrm{E}-10$ \\
\hline
\end{tabular}

Table 3.3. Hydraulic Conductivity of Polymer-Modified Asphalt Membrane Samples from the Prototype Barrier

\begin{tabular}{||c|c|c|l||}
\hline \hline Sample & Thickness (cm) & $\begin{array}{c}\text { Hydraulic Conductivity } \\
(\mathrm{cm} / \mathrm{s})\end{array}$ & \multicolumn{1}{||}{ Description } \\
\hline \hline 1 & 0.160 & $1.36 \mathrm{E}-11$ & FAA applied to geofabric \\
\hline 2 & 0.265 & $1.18 \mathrm{E}-11$ & Sample taken on 5/15/94 \\
\hline 3 & 0.275 & $2.49 \mathrm{E}-11$ & Sample taken from strip z \\
\hline 4 & 0.500 & $2.51 \mathrm{E}-11$ & Sample taken from strip AA \\
\hline \hline Average & 0.300 & $1.88 \mathrm{E}-11$ & \\
\hline
\end{tabular}

test area. Tests were orininated in September 1994 and should be completed by November 1994. TwoFFHP tests will be run near the SDRI tests for direct comparison of the techniques.

\subsubsection{Summary}

Hydraulic conductivity was measured on HMAC and FAA materials used as asphalt layer components in the prototype barrier. Field measurements were biased by water leakage along the permeameter wall but exhibited values that ranged between $1 \mathrm{E}-09$ and $1 \mathrm{E}-07 \mathrm{~cm} / \mathrm{s}$. The highest value was associated with a single sample taken from a seam in the asphalt layer. HMAC cores that were tested in laboratory permeameters were found to have hydraulic conductivity that averaged $1 \mathrm{E}-10 \mathrm{~cm} / \mathrm{s}$. FAA run in laboratory permeameters had even lower conductivity values, averaging $2 \mathrm{E}-11 \mathrm{~cm} / \mathrm{s}$. Sealed double ring infiltrometer tests have been initiated at the asphalt layer test pad, and results should be available in November 1994. 


\subsection{Wind Erosion Monitoring Task}

Monitoring work was initiated to study the influence of eolian stresses on the stability and function of the admixture surface of the prototype barrier. As a part of this effort, measurements are being performed to validate the selection of test parameters in past wind tunnel tests that provided designbasis information for the surface layer. The influence of wind on the two types of side slopes is also being monitored. Most measurements are being made over the south, nonirrigated half of the prototype barrier where erosive stresses are maximized and most closely represent the worst-case conditions needed for wind erosion monitoring. While normal erosion events are of interest, monitoring systems were designed for continuous use to ensure data are obtained in the event of the occurrence of highintensity wind storms ( $>10$-year return period).

\subsubsection{Wind Erosion - Scope and Objectives}

The construction of a full-scale prototype surface barrier at the Hanford Site provides an opportunity to monitor actual conditions and effects of wind on the surface and to compare these results with assumptions made during wind tunnel tests. The results of wind tunnel tests of simulated surface layer admixtures, reported previously by Ligotke and Klopfer (1990) and Ligotke (1993), provided information with which to develop the design basis of the surface layer of the prototype barrier. The scope and objective of several wind erosion monitoring activities were listed and described briefly by Gee et al. (1993) and, in modified form, include:

- Monitor the influence of eolian stresses on the surface layer as it ages under irrigated and natural conditions after disturbances caused by construction and subsequent establishment of vegetation

- Measure actual rates of surface deflation or inflation

- Obtain micrometeorological information about erosive shear stresses that impact the barrier

- Obtain information about abrasive sand particle scouring (saltation).

In addition, two other testing and monitoring objectives were proposed for the period after most other monitoring activities have ceased, presuming site restrictions and work priorities permit:

- Create a sand dune and monitor its impact on surface erosion, plant community viability, and soil reservoir water balance

- Remove established vegetation using fire or other means, and study the erosive impacts under conditions simulating post-wildfire or extended drought. 


\subsubsection{Wind Erosion Testing and Monitoring Activities}

Four wind erosion testing and monitoring activities were initiated on the surface of the prototype barrier. Descriptions of activities are based on the test plan by Gee et al. (1993) and work performed at the prototype barrier through early September 1994. Two additional proposed follow-on tasks (Sections 3.2.2.5 and 3.2.2.6) are also described, and if approved, will be performed late in the testing and monitoring period.

\subsubsection{Surface Layer Composition}

The surface layer (top $1 \mathrm{~m}$ of soil) was amended by adding $15 \mathrm{wt} \%$ pea gravel. The gravel was added to act as an agent to erosion during periods following construction, wildfires, droughts, or other periods of susceptibility to eolian stresses. The decision to use $15 \mathrm{wt} \%$ pea gravel was based in part on the results of wind tunnel tests (Ligotke and Klopfer 1990, Ligotke 1993), and was also a compromise with the needs of water storage in the surface layer. The constructability of an admixture on the scale of the prototype surface layer was evaluated. Questions resolved during this early period of testing and monitoring included 1) were practical difficulties encountered during construction and 2) was it possible to maintain a uniform admixture composition?

The preparation and placement of the 1-m-thick pea gravel admixture did not pose unusual construction difficulties. A pug-mill operation was set up at the construction site to mix clean pea gravel with silt loam from the same source used to construct the lower soil layer. The material was dumped on the surface and then shaped using a tracked caterpillar. The final surface was ripped to provide a surface density within specifications. The concentration of pea gravel near the surface appeared to be fairly uniform.

\subsubsection{Surface Layer Deflation/Inflation Monitoring}

The suitability of a $15 \mathrm{wt} \%$ pea gravel admixture placed in the top 1-m soil layer to provide resistance to soil erosion by wind will be tested during deflationary periods such as those present immediately following construction. The long-term condition of the surface as it ages under both deflationary and inflationary influences will be monitored to evaluate performance. Answers to the following questions will reveal the ability of the surface to resist eolian stresses. What is the distribution of pea gravel at the surface, and does it change compared with its bulk distribution in the soil layer? When deflationary conditions prevail, are measured rates of erosion comparable to wind tunnel test results? Does a pea gravel armor form and reduce rates of erosion, and do scoured areas form near upwind edges or in other areas? When inflationary conditions prevail, do sand deposits form? Does the distribution of pea gravel change at the surface? What erosion or deposition occurs on the side slopes, and how does orientation and slope influence side-slope erosion or deposition?

Testing and monitoring activities were initiated in late August 1994, and included the collection of 24 evenly spaced samples of the surface layer. The samples were obtained immediately after 
construction (and after the surface was ripped to decrease density) and before redistribution by erosion had occurred. The samples were scooped from the surface to a maximum depth of about $7 \mathrm{~cm}$ and contained bulk masses between 1.5 and $2.0 \mathrm{~kg}$. Pea gravel concentration was determined as the mass of pea gravel per the combined mass of dried soil and pea gravel. The average of all samples indicated a pea gravel composition of $14 \pm 2 \mathrm{wt} \%$. The measurement uncertainty was determined as one standard deviation of all samples. The results indicated that the northern half of the top surface of the barrier potentially contains pea gravel concentrations that are 10 to $15 \%$ higher. The pea gravel concentrations were $14.7 \pm 1.7,14.8 \pm 2.6,13.6 \pm 1.3$, and $12.5 \pm 1.0 \mathrm{wt} \%$ in the NW, NE, SE, and SW quadrants, respectively. The average from each quadrant was based on six samples. Because of the relatively small number of samples and the large surface area, the results provide only an indication of pea gravel uniformity.

Continued sampling will be done annually, or more often if the appearance of the surface changes significantly. Subsequent samples of the aging surface will be separated into two depth categories: 0 to $2 \mathrm{~cm}$ and 2 to $10 \mathrm{~cm}$. Additional information on surface deflation or inflation will be developed based on the results of periodic surveys. Also related to the survey task, erosion pins will be used to document local surface elevation changes. Changes in surface elevations or pea gravel concentrations will be documented and compared with conditions existing immediately after construction. It will be determined whether or not correlations exist between surface characteristics and deflation, inflation, and surface shear stresses (wind and sand saltation).

\subsubsection{Wind Stress Monitoring}

Monitoring was initiated in FY 1994 to provide information on the stresses imparted by wind on the surface of the prototype barrier. This was accomplished by installing two of three planned wind boundary layer stations. The objective is to answer questions related to the surface shear stresses imparted by wind on the top-center, top-edge, and approach (control) surfaces on and near the barrier. The following testing and monitoring questions are being addressed. Are peak values of wind stress comparable with, but less than, published values and those selected for wind tunnel tests? How much larger are wind stresses at the prototype top elevation than at ground level? Is the difference significant with respect to the ability of the barrier to resist deflation?

The two wind stations located on the top-center and top-edge of the barrier were installed in late August 1994. The third station, to be located to the southwest of the barrier, will be installed after construction equipment has been demobilized. Wind speed sensors were installed at each station at elevations of $0.25,0.50,1.0$, and $2.0 \mathrm{~m}$ above the surface. Wind direction and air temperature sensors were installed at each station. A solar radiometer was installed at the top-center station. The stations were connected to a dedicated datalogger. The calibration of anemometers was checked in a wind tunnel, the direction sensors were aligned to read $0 \circ$ when directed true north (assuming a declination of $18 \circ$ ), and the connection and output of each sensor to the datalogger was checked and validated. Measurements are recorded hourly and on 10-min intervals. A threshold wind speed, initially set at $5 \mathrm{~m} / \mathrm{s}(11 \mathrm{mi} / \mathrm{hr})$ and then increased to $7.5 \mathrm{~m} / \mathrm{s}(17 \mathrm{mi} / \mathrm{hr})$, caused data to be stored on the shorter 
interval to provide detailed information during windy periods. In addition to recording average wind speed data, the hourly output included the magnitude, direction, and time of the peak gust, and the 10-min output included similar information (for each anemometer) on the shorter cycle. A procedure for converting data files to data records was developed, and methods for selecting wind speed records for surface shear stress calculations will be developed in FY 1995. Also planned is use of a surface moisture probe at each wind station to provide information on the potential for soil erosion by wind. Data will be obtained continuously, and success of the monitoring will depend on obtaining data during the most significant wind events during the 3-year monitoring period.

Relative to their return period, peak wind shear stresses are expected to be comparable to those applied to physical models in a wind tunnel. The maximum stresses should range between roughly 2 and $4 \mathrm{~N} / \mathrm{m}^{2}$. Stresses near the center of the barrier are expected to be greater than those at grade level and less than those near the edges. The relatively strong edge region shear stress is expected to be greatest near the steep basalt side slope and least near the graded side slope. Although the surface layer should be able to resist wind stresses, the stresses present during the failure of any component of the barrier (surface layer, vegetation, side slope, etc.) during any extreme wind events will be characterized.

\subsubsection{Monitoring Saltation Stresses and Sand Drift Potentials}

The movement of wind-driven sand over the surface of the barrier is expected to be the mechanism by which loss of surface soil occurs. Measurement of the stresses and drift rates of soil and sand over the surface of the barrier will provide an important measure of the magnitude of eolian stresses resisted by the pea gravel admixture. A series of questions are being addressed. Are peak values comparable with, but less than the published values selected for wind tunnel tests? Are sand particle saltation stresses and sand drift potentials at the top surface of the monitored barrier greater or less than those at ground level? Is the difference significant with respect to the capacity of the barrier to resist deflation?

Testing and monitoring work was initiated in FY 1994 by installing three multisensory saltation stations near the eastern side of the southeast quadrant of the barrier surface. Earlier in the year, automated saltation sensors and dust traps were obtained and validated in a wind tunnel. The sensors, with cylindrical cross sections to eliminate dependence on wind direction, provide a count record of sand grain impacts and a time record of the total kinetic energy of each erosion event. The dust traps, each with an attached wind vane, remain directed into the wind and collect physical samples of silt particles and sand grains.

Two of the saltation stations consist of collocated sensors and traps, each set $2 \mathrm{~m}$ above the surface. The third station includes multiple collocated sensors at $0.25,0.50$, and $1.0 \mathrm{~m}$ elevations and dust traps at $0.125,0.25,0.50$, and $1.0 \mathrm{~m}$ elevations. The third station was included to provide information on the vertical distribution of wind-driven sand and soil particles, which will be used in evaluating total soil and sand mass flow rates over the surface. A dedicated datalogger is used to record data from the 
sensors and to initiate data acquisition only during wind storms, based on feedback from a wind speed sensor with a threshold setting currently at $7.5 \mathrm{~m} / \mathrm{s}(17 \mathrm{mi} / \mathrm{hr})$. Dust traps are sampled manually after significant wind storm events.

The results of saltation measurements will be compared with wind boundary layer and surface shear stress information (Section 3.2.3) to identify stresses and evaluate the resistance of the surface to eolian erosion. Saltation stresses are anticipated to be greater on the surface of the prototype barrier than on the surrounding desert. This is because prevailing winds are likely to drive saltating sand along the graded side slope and to the top of the barrier surface. If present, saltating sand could provide the dominant erosive force on the surface of the barrier. Monitoring data will be used to quantify and evaluate the presence and influence of saltating sand grain shear stresses on the barrier surface. These stresses are expected to be equal to or less than the sand flux rates applied to physical models in a wind tunnel. Measured rates of sand transport will be correlated with meteorological and surface conditions and compared with published estimates.

\subsubsection{Monitoring an Artificial Sand Dune}

No work was performed on this task in FY 1994. A detailed description of the task was provided by Gee et al. 1993. Work to monitor a sand dune placed on the surface of the prototype barrier is planned to be initiated in FY 1997 or FY 1998, with final planning and preparations made early in the year, placement in June, and monitoring performed between June and December of the year work was initiated.

\subsubsection{Monitoring a Post-Wildfire Surface}

No work was performed on this task in FY 1994. A detailed description of the task was provided by Gee et al. 1993. Work to monitor the surface after an actual or simulated wildfire removes surface vegetation is under consideration for FY 1998; however, final authority to perform such a test depends on resolving site use issues.

\subsubsection{Wind Erosion - Conclusions and Recommendations}

Testing and monitoring activities to document, measure, and evaluate the influences of wind-and sand-caused eolian erosion stresses were initiated following the test plan described by Gee et al. 1993. In FY 1994, final planning was performed, instruments were procured, sampling systems were assembled, and data acquisition was initiated. Baseline information regarding the condition and composition of the surface was obtained. Data files were generated that included wind boundary layers, saltating sand drift potentials, and dust/sand surface mass fluxes. Data acquisition, analysis, and interpretation is planned to continue as the barrier ages over a 3-year period. 


\subsection{Water Erosion Monitoring}

The plan for monitoring the barrier's soil surface proposes to collect data and information on the erosional behavior of the soil under natural rainfall and snowmelt conditions (Gee et al. 1993). The dominant erosional processes are rainsplash coupled with overland runoff in which rainsplash loosens soil particles and makes them available for transport by runoff. To reduce soil erosion, the prototype barrier uses both a pea-gravel admix and vegetation to reduce rainsplash erosion. The gravel admix was blended with the soil during construction and vegetation will be added after construction.

Another factor contributing to erosion is runoff volume. For a given rainfall event, as the slope length and surface area increases, the volume of runoff increases. The prototype provides an opportunity to monitor a representative length of barrier and surface area under local climatic conditions. The monitoring plan consists of two separate data collection efforts: 1) measurement of runoff and sediment yield from a 6-m-wide $\times 15$-m-long flume installed on the soil surface (controlled-area monitoring), and 2) observation and documentation of the effects of precipitation over the larger remaining surface area (barrier-surface monitoring).

As part of the barrier-surface monitoring, the interface of the soil surface and rock riprap side slope will be included in the observations. The rock side slope will not be subject to erosion, but soil erosion may develop at the interface caused by the loss of soil and filter material through the larger interstitial areas of the mounded rock.

\subsubsection{Objective}

The changes occurring on the soil surface due to erosion and "soil-surface aging" under natural climatic conditions will be documented. The collected data will include measurements of changes in engineering soil properties at the surface, documentation of erosional patterns, the effects of vegetation on erosion, and disturbance by animals. The results will also provide supporting data and information to other tasks.

As part of the surface monitoring program, rock creep gauges have been installed in the rock riprap side slope to detect any movement (potential failure) of the rock mass (see Figure 3.2). Ensuring structural stability of the rock slope is necessary in order to maintain the integrity of the barrier.

\subsubsection{Monitoring Approach}

A 3-m x 3-m grid system was established on the soil surface to provide a ready field reference system to map surface changes. The system was established by setting four corner markers composed of steel rebar enclosed in 7.6-cm (3-in.) PVC that define a 36-m x 75-m rectangle composed of steel 


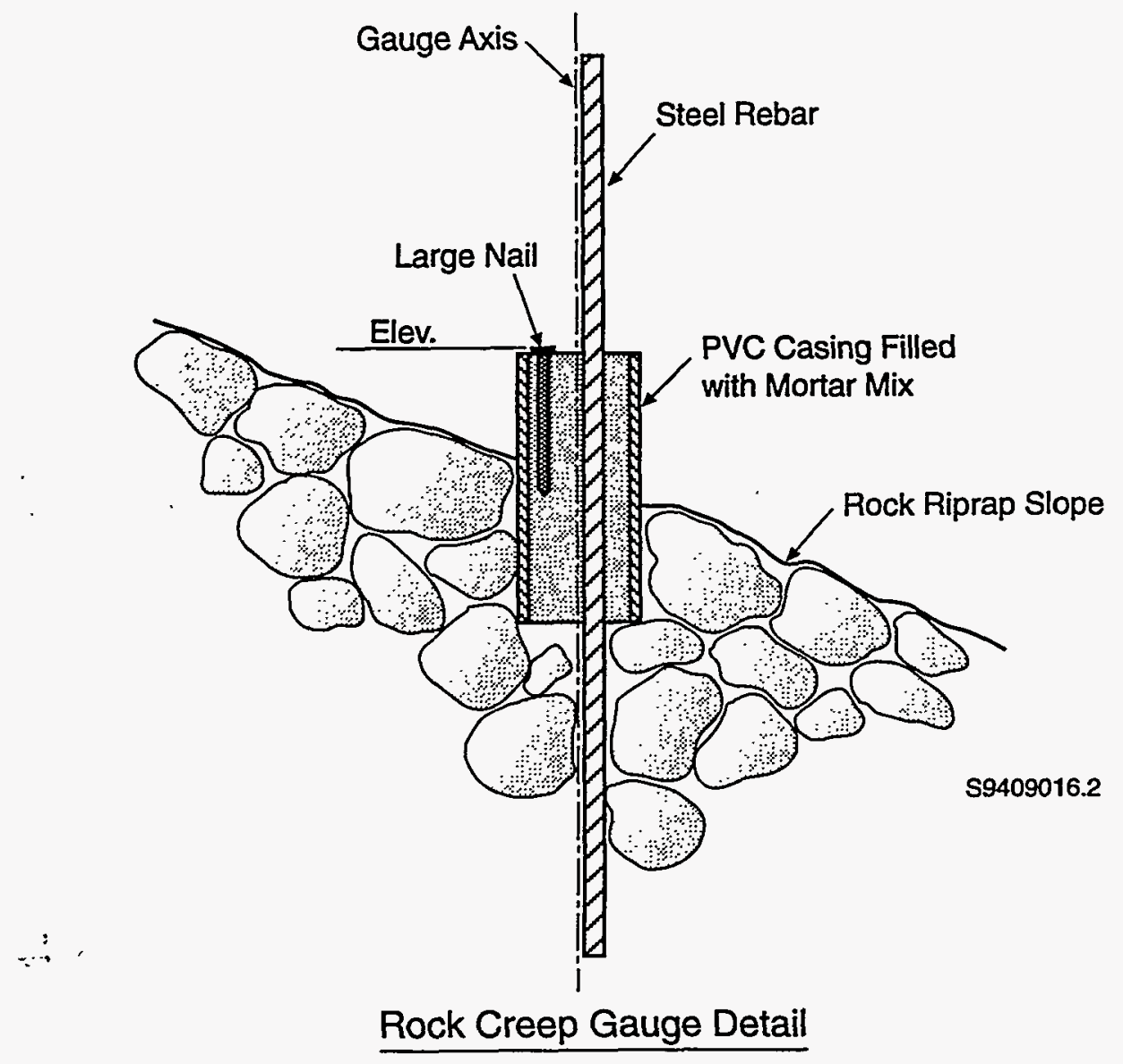

Figure 3.2. Rock Creep Gauge for Basalt Side Slope Stability Test

rebar enclosed in 7.6-cm (3-in.) PVC that define a 36-m x 75-m rectangle visually centered within the perimeter of the compacted gravel roadway (see Figure 2.2). Interior grid points were established using painted wood surveying stakes. These were placed to define the $3-\mathrm{m} \times 3-\mathrm{m}$ grid and numbered to identify grid coordinates.

The rock creep gauges were installed at 11 locations along the rock slope. At each location, the gauges were placed at the slope midpoint except for one location near the northeast corner where two gauges were installed on the upper and lower slope elevations. Figure 2.2 shows the grid system and rock creep gauge layouts. Figure 3.2 shows the gauge design.

Profile leveling survey methods were used to determine the elevations at each grid point and gauge. The gauge plan positions were surveyed with EDM surveying equipment. All elevations and positions will be checked either seasonally or annually. Soil properties, such as density and moisture content, will be measured monthly or seasonally. Soil surface changes, such as cracking and rill development, will be monitored with photography and located with respect to the grid layout. 
To begin the monitoring, four data collection trips are planned on a seasonal basis during the first year. As experience is acquired with the prototype, monitoring may be conducted as needed and modified based on precipitation and snowmelt events.

\subsubsection{Expected Results}

Contour maps of the soil surface elevations and post construction soil properties will be developed. Seasonal or annual changes in the elevations and properties will be documented over the life of the prototype barrier. Maps showing changes in vegetation cover and animal burrowing will be developed to relate those changes to erosional trends. The mapping will document the degree of nonuniformity of near-surface moisture (localized accumulations) together with the other soil properties and changes in those properties over the monitoring time frame. Their relationship to erosion and infiltration will be investigated in cooperation with other tasks.

\subsubsection{Controlled Area Monitoring}

The objective of this effort will be to monitor the water and sediment yield of the 6-m $\mathrm{x}$ $15-\mathrm{m}$ flume with an automated flow measurement and sampling system operating on the occurrence of rainfall and snowmelt events.

The flume was constructed of timber with an opening at the downslope end. A galvanized collector system receives the water-sediment runoff for conveying the mixture to the automated monitoring system. The flume location is shown in Figure 2.2. The automatic sediment sampling system was installed on the west side of the gravel road and connected to the flume by a buried plastic pipe.

The automated system consists of a sediment collector to accumulate runoff and sediment. Flow meters measure the flow at the collector. Soil moisture probes, thermocouple temperature indicators, and a snow gauge will record snowmelt events. A rain gauge will be used as a backup system to validate rainfall at specific locations.

The flume monitoring will run concurrently with the barrier surface monitoring. The onsite servicing of the collector system will depend on the extent of precipitation and snowmelt events.

\subsubsection{Expected Results}

Time-varying measurements of overland runoff from rainfall and snowmelt events and corresponding sediment yield will be obtained. The data will be used to analyze soil erosion from precipitation falling on the barrier surface and the corresponding changes in erosivity as the surface ages. These results will provide information that will enable evaluation of the barrier soil's capacity to resist water erosion. 


\subsection{Water Balance Tests}

The prototype barrier provides a full-scale facility needed to quantify the performance of surface barriers in limiting water infiltration into underlying wastes at the Hanford Site. The prototype will be tested under normal and extreme (precipitation) conditions and water balance data will be collected for a minimum of three years. Test equipment installed in the prototype barrier in September 1994 will allow detailed measurements of individual components of the water balance (precipitation, water storage, and drainage) over space and time. These data, coupled with hydraulic property and plant characterization data, can be used to assess long-term performance of surface barriers by providing verification checks for hydrologic models used to predict barrier performance for up to 1000 years or more.

\subsubsection{Water Balance Scope and Objectives}

The scope of the water balance task is to make detailed measurements of water balance parameters on the prototype barrier for a minimum of three years and to prepare high quality data sets that can be used to test predictive models needed to evaluate barrier performance for up to 1000 years or more. The objectives of this task are to quantify drainage rates from soil surfaces subjected to normal and extreme (1000-yr-return) precipitation events, to measure drainage from coarse side slopes of the prototype barrier, to develop a cost-effective method to measure water storage changes in surface barriers, and to provide sets of complete, multi-year, water balance data that can be used to prove effectiveness of barrier design for extended times. These objectives are designed to support Hanford Site Operable Unit needs for on-site barrier performance data. They are also designed to assist in sitewide feasibility studies in which surface barrier alternatives may be considered.

\subsubsection{Water Application and Measurement}

Water was applied to the prototype barrier in early September 1994 using impact sprinklers. Approximately $150 \mathrm{~mm}$ of water was applied over the entire soil surface. This water was applied before installing monitoring equipment and was necessary because dry surface conditions were present when the barrier was completed. After water application, surface settlement of about $10 \mathrm{~cm}$ was observed on the northwest end of the barrier. The water content increased from about $5 \mathrm{wt} \%$ to more than $10 \mathrm{wt} \%$ in the top meter.

Scheduled water applications will begin in November 1994. Water will be applied to the north half of the barrier via irrigation and snow. Application rates will be similar to those used in testing Hanford covers at the Field Lysimeter Test Facility (FLTF). Water will be applied at the rate of $480 \mathrm{~mm} / \mathrm{yr}$ for the next 3 years on two test plots of the prototype barrier. The application will include biweekly irrigation except in winter. In winter, snow applications by means of a snow machine (see Appendix) will be made at rates three times the normal snowfall $(130 \mathrm{~mm} / \mathrm{yr})$. Thus, there will be 
three applications in the winter that will deliver $130 \mathrm{~mm}$ of water with each application. The times for application will be weather dependent but will occur between November and March each year. In late March, there will be an irrigation at a rate equivalent to a $1000-y r$ storm. Over a $24-\mathrm{hr}$ period, $68 \mathrm{~mm}$ of irrigation will be applied to the north half of the barrier.

Precipitation will be measured with 12 mini-lysimeters that were installed on the barrier surface in September. The mini-lysimeters were constructed by placing $20-\mathrm{L}$ plastic containers on electronic load cells and lowering them into the ground inside a slightly larger in diameter, heavy-walled plastic tube. The tube acts as the outer wall of the lysimeter. A round-bottomed, plastic flowerpot sits inside each 20-L container and is positioned so that it rides freely in the 20-L container and is recessed below the top of the outer wall. The pot has been filled with white marbles that have low water storage, allowing rapid drainage of water during and after precipitation events. The top of the lysimeter is covered with a grill that has about 5-cm horizontal spacings allowing water and snow to readily enter the lysimeter. The open-surface cover was designed to allow the mini-lysimeter to capture and weigh snow directly. This allows the measurement of rainfall, irrigation, and snow with one instrument. Six units have been placed in an east-west line on the north (irrigated) end of the prototype, and six units have been placed similarly on the south end of the prototype. Snow depth will also be measured with gauging instruments both electronically and manually.

\subsubsection{Water Content and Water Storage Measurement}

A series of instruments will be used to measure soil water content and soil water storage. These instruments include neutron-neutron (downwell-probe) devices, electrical capacitance, and time domain reflectometry. In addition, noninvasive methods to periodically measure water content and storage are planned using electromagnetic induction and ground penetrating radar surveys.

\subsubsection{Neutron Probe}

Neutron probes (neutron-neutron logs) will be used to measure volumetric water content of the soil profile. The neutron probe monitoring at the prototype will include monitoring of the surface soil profile through vertical access tubes (50-mm-dia. x 2-m-deep) and also monitoring water contents of underlying layers through long, horizontal access tubes (65-mm-dia. and up to 32-m-long).

Two series of six vertical access tubes each were installed $2 \mathrm{~m}$ deep in the surface soil in September 1994, after completion of the prototype. Water content data from these access tubes will be measured biweekly and entered into the data base. The water content data will be integrated and converted to water storage. Horizontal profiles of soil water will also be taken routinely. Water contents at the bottom of the soil layer (just above the soil/sand interface) and underneath the barrier (below the asphalt layer) will be measured through access tubes installed during the construction of the prototype (DOE 1994). The horizontal logs will be used to determine the spatial variations in depth of water penetration within and at the edge of the barrier. 
The neutron probe requires field calibration. Cores taken adjacent to selected vertical access tubes will be sampled for gravimetric water content and bulk density. These data will then be used to determine the volumetric water content of the soil. Neutron probe counts will be compared to the water contents, and subsequently a calibration will be established for the vertical access tubes. A similar calibration procedure will be used for the horizontal access tubes except that soil water contents will be taken only from locations surrounding the lowermost access tubes, in areas where soil samples can be readily taken.

\subsubsection{Electrical Capacitance}

Electrical capacitance will also be used to measure volumetric water content. A commercially available capacitance probe will be used to $\log 2$-m-deep soil profiles by lowering a cylindrical probe down small (50-mm-dia.) plastic access tubes. The electrical capacitance of a soil is dependent upon both salt and water content of the soil. If the salt content remains constant, the changes in capacitance can be calibrated in terms of the soil water content alone. The access tubes are located $45 \mathrm{~cm}$ from the neutron probe access tubes. The capacitance probe calibration will be accomplished by measuring the water content and bulk density of the soil during coring and placement of the access tubes in the center of the buffer zone. Some additional water content and bulk density samples may be taken following irrigation if the range of water contents obtained in the initial coring is not sufficient to cover the expected range of water contents.

\subsubsection{Time Domain Reflectometry}

Time domain reflectometry (TDR) (Topp et al. 1980, Hook et al. 1992) will also be used to measure volumetric water content in the soil profile. TDR is based on measurement of the velocity of propagation of a high frequency electromagnetic wave in metallic waveguides (probes) inserted into the soil. The velocity of propagation varies inversely with the square root of the dielectric constant of the soil. The dielectric constant of the soil is highly dependent upon the soil water content. The dielectric constant for water is about 80 and ranges from 2 to 7 for mineral soils. Thus, the TDR propagation velocity is uniquely related to the effective soil dielectric, which in turn is a measure of water content. The advantage of TDR over conventional neutron probe logging is that TDR can be automatically logged on virtually a continuous basis and the data collected remotely through electronic means. The relationship between volumetric water content and the dielectric constant is essentially independent of texture, porosity, and salt content. Thus, there is no need for field calibration to account for these factors. Further, there is no radioactivity or associated radiation safety concerns. Recent advances in TDR probe technology make it possible to obtain water content profiles with a single segmented probe. This probe, which employs a variation of TDR known as remote sensing diode shorting (Hook et al. 1992), will also be used to measure volumetric water content in the soil profile. The Appendix provides vendor information on these probes.

A series of 12 segmented TDR probes were installed in the surface of the prototype during September 1994. Two additional probes were installed in the clean-fill side slope in October 1994. 
These units are specially constructed probes configured with eight-remote shorting diodes. This design allows the measurement of water content across seven segments of a 185-cm-long probe, buried vertically in the ground. The probes are connected, via two eight channel multiplexers, to a TDR controller and readout unit. This will allow the automatic logging of water contents of the prototype barrier surface at preset time intervals. From these data, profiles of water content across the irrigated and nonirrigated sections of the prototype will be displayed and documented. Both profiles and water storage (integrated profile data) will be stored in the data base. Weekly summaries of these data will be provided for review and analysis.

\subsubsection{Noninvasive Techniques}

Techniques such as TDR and neutron attenuation are limited to near-surface measurements and are impractical for large-scale surveys. These techniques are also difficult to use in the presence of hard surfaces (e.g., concrete, asphalt, etc.) unless probes and access tubes are inserted during construction. Noninvasive methods, such as electromagnetic (EM) induction and ground-penetrating radar (GPR), may overcome these limitations. The EM technique has been applied to the measurement of spatial and temporal changes in soil water content (Kächanoski et al. 1988). The response of GPR, as with TDR, is governed by dielectric properties of the medium. A recent study by Du and Rummel (1994) demonstrated that GPR can be used successfully to measure water content. Both methods are currently available and have been used for detecting buried objects. However, the use of these techniques for profiling water content in the vadose zone has not been evaluated. Because of the noninvasive features of these devices, they could be useful for routine monitoring of water content of surface barriers at the Hanford Site.

During September 1994, Dr. Jan Hendrickx of New Mexico Tech, Socorro, New Mexico, collaborated with PNL to measure the prototype barrier surface using EM meters (Geonics, type EM-31 and EM-38 meters). Surveys were taken on the soil surface of the barrier. The data will be used in connection with the water content data, measured by neutron probe, to develop an appropriate calibration for EM meters to monitor the surface of the prototype for water content. Additional surveys will be made over the course of the next year at times when neutron, capaci-tance, and TDR probe data are being collected. When this work is completed, it should be possible to correlate the water content profiles obtained from neutron probes, capacitance probes, and TDR with signal characteristics from both the EM meters and using GPR units. The dielectric measurements obtained from TDR and capacitance probes will provide excellent reference data for GPR measurements for soil water content. Because of its well-defined features, the prototype barrier provides an excellent facility for calibration of noninvasive devices for monitoring water content profiles and evaluating water storage of surface barriers.

\subsubsection{Drainage Measurements}

Drainage from the prototype is measured in a collection system that has been specially made for the prototype barrier. During construction, a series of curbs and gutters were placed on the asphalt 
concrete such that the asphaltic concrete is divided into 12 distinct plots or areas (DOE 1994). Gutters connect to drain pipes that slope off the asphalt layer to the north of the prototype where they connect to water-tight concrete vaults (see Figure 1.2). The vaults contain dosing siphons (Orenco Systems, Inc., Roseburg, Oregon) that automatically dose (drain) fixed volumes of water (about $650 \mathrm{~L}$ ) repeatedly. The siphons are made of corrosion resistant plastic and have no moving parts.

During installation of the drainage system in May and June 1994, electronic counters (siphon sitters) were connected to the siphons. Leak tests and drainage tests were conducted in May. Lines were initially pressurized checked to ensure they were sealed, then water was added at the gutter end of the drainage pipe, and water flow into the dosing vault was measured. Data from the drainage tests indicated that there was essentially $100 \%$ recovery for all dosing siphons, when evaporation and line storage were accounted for.

In September 1994, tipping buckets, pressure transducers, and thermocouples were installed in all of the concrete vaults. The tipping buckets and pressure transducers will be used to detect low flow rates (less than $2 \mathrm{~mm} / \mathrm{yr}$ ) and the siphon sitters will be used to detect higher flow rates. Based on the area of the plots (which range from 92 to $322 \mathrm{~m}^{2}$ ), effective area of the dosing vault $\left(1.1 \mathrm{~m}^{2}\right)$, and the sensitivity of the pressure transducer (about $0.5 \mathrm{~mm}$ elevation, equivalent to less than $0.005 \mathrm{~mm} \mathrm{H}_{2} \mathrm{O}$ ), we estimate that the resolution of drainage as calculated by change in water elevation in the dosing vault will range from 0.02 to $0.06 \mathrm{~mm}$ of water. This is about an order of magnitude below the barrier drainage design objective (i.e., $0.5 \mathrm{~mm} / \mathrm{yr}$ water drainage).

The vaults are closed, and evaporation is expected to be small. Small evaporation meters (waterfilled, plastic tubes) have been attached to the inlet pipe of each dosing siphon, and monthly evaporation rates will be recorded for each drainage vault. Errors in drainage measurement due to evaporation are estimated to be no more that $0.04 \mathrm{~mm}$ of water per year.

\subsubsection{Other Measurements}

Thermal profiles and water suction (negative of matric water potential) data will also be collected at the prototype barrier. Temperatures will be measured using copper-constantant thermocouples. The . temperature profiles will be part of the environmental data used to determine frozen soil conditions (for estimating water or snow application rates) in winter and to profile soil heat loading in spring and summer for estimating water losses from barrier surfaces. Soil water suction data were obtained from heat dissipation units (Campbell Scientific Co., Logan, Utah). The soil water suction data will be measured concurrently with TDR-measured water storage. These data will provide a means to obtain in-place hydraulic property data for the prototype soil surface. The temperature will be monitored hourly, and the soil water suction will be monitored daily. Strings of thermocouples and heat dissipation units were installed at 12 water monitoring stations in the soil surface in September 1994.

Fiberglass blocks, thermocouples, and pressure tubes were installed to monitor horizontal profiles at the 2-m soil depth and also below the asphalt layer. Fiberglass blocks will be used to provide a 
qualitative measure of soil suction. There were 18 fiberglass sensors in all: six are located in an array under the northeast section of the asphalt pad, six are located at the 2-m depth beside a horizontal access tube in the NE section of the soil cover, and six are at 2-m depth in the SE section of the soil cover.

\subsubsection{Summary}

Water balance instrumentation has been installed on the prototype barrier, and testing is scheduled to begin in November 1994. Irrigation and measurements of precipitation, water storage, and drainage will be initiated at that time. Precipitation will be monitored by means of electronic load cells. Water storage will be monitored periodically by neutron and capacitance probes. Water balance will be measured by using TDR probes that are logged electronically. Water suction and temperature also will be logged electronically and data will be stored in the prototype data base. Drainage data will be collected electronically from dosing counters, tipping buckets, and pressure transducers. Estimated resolution of drainage from the dosing siphons range from 0.02 to $0.06 \mathrm{~mm}$ of water, about an order of magnitude below the barrier design objective of $0.5 \mathrm{~mm}$ drainage per year.

\subsection{Biointrusion}

Plants and animals will play a significant role in the hydrologic, water, and wind erosion characteristics of the prototype barrier (Link et al. 1994). Studies conducted on the biological component of the prototype barrier in FY 1994 included the initiation of the revegetation task for the surface plus the planning and acquisition of equipment needed to monitor plant transpiration, root characteristics, and the effects of burrowing animals on surface characteristics. These efforts will begin in FY 1995 and will be conducted in concert will other monitoring efforts.

\subsubsection{Vegetation Establishment and Monitoring}

Plants will play a central role in the prototype barrier. Plants will extract, by transpiration, at least two times as much water from fine silt-loam soils as will be lost by soil evaporation alone. Plants will also minimize wind and water erosion (Link et al. 1994). It is critical that a sustainable plant community be established on barrier surfaces. During the construction of the prototype barrier, revegetation efforts centered around preparation for the planting of shrub seedlings. Planting will occur during the fall of 1994 after seasonal rains begin.

Seeds of the shrubs, Artemisia tridentata and Chrysothamnus nauseosus were collected from McGee Ranch on the Hanford Site on December 23, 1993. The entire inflorescence of $A$. tridentata and the fruits of $C$. nauseosus were harvested and stored in plastic bags in the field. The material was transported to the Arid Lands Ecology (ALE) laboratory facility, taken out of the plastic bags, and placed on table tops to dry. The material was stored this way in the dark and at room temperature until it was shipped to a nursery. The uncleaned, dry material was shipped to Plants of the Wild (Tekoa, Washington) on March 11,1994. The seed was cleaned for germination by April 12. All the seed was 
sown on May 4. Germination was complete by about June 10 , with a germination success of $40 \%$ for $C$. nauseosus and $60 \%$ for $A$. tridentata. There are approximately 2500 seedlings of $C$. nauseosus and 7500 seedlings of $A$. tridentata. Seedlings (tublings) were grown in $164 \mathrm{~cm}^{3}\left(10 \mathrm{in}^{3}\right)$ tubes.

The seedlings will be shipped for planting in October or November, depending on the weather. The surface of the prototype will be modified by hydroseeding a mix of native grass and forb seed, nitrogen, organics and a tacking agent. This material will be watered into the surface to drive nitrogen into the soil. The shrub seedlings will then be planted onto the surface. The surrounding slopes and toe of the prototype barrier will also be revegetated and treated with the hydroseeding mix in October or November. A successful revegetation effort will result in the development of a perennial deeprooted native plant community on the surface.

The developing plant community will be assessed to determine shrub establishment success, grass establishment from seed, and the incursion of alien species such as Salsola kali during FY 1995. The occurrence, growth, leaf area, and soil water extraction ability of plants (transpiration) will be monitored on the prototype surface and along the toe of the barrier.

\subsubsection{Root Intrusion/Root Distribution}

Root intrusion and distribution with depth will be monitored with minirhizotrons. Twelve clear tubes will be drilled into the soil to the bottom of the silt-loam soil layer to document rooting depth, root growth, and rooting density with depth. These tubes will be placed near neutron access ports so that root characteristics can be associated with soil water dynamics. Root characteristics .will be observed with a down-well camera inserted into the clear tubes. These data are necessary to document the rate of growth and depth of roots on the surface and for the simulation soil water dynamics on the surface.

\subsubsection{Animal Intrusion Subtask}

Animals will colonize the barrier and burrow into the surface. Animals are instrumental in pedoturbation, surface hydrology, plant community dynamics, water erosion, wind erosion, and the potential compromise of barrier layers by deep burrowing (Link et al. 1994).

The occurrence and effect of animal burrows on the prototype will be documented over the course of the observation period. Data will be collected quarterly and will include the date, burrow hole ID number, coordinate location, map location, animal species (if identifiable), hole diameter to nearest $0.5 \mathrm{~cm}$, photograph with $3 \times 5$ card showing hole $\mathrm{D}$ number, and a description of cast soil at the surface (admix composition). 


\subsection{Data Base Subtask}

The prototype barrier is a multi-disciplinary project that will generate large amounts of data from diverse sources. The goal of the data base subtask is to create a data repository for the collected data. The information resource dictionary (IRDS) is an ancillary data base that will contain descriptions of the data. This ancillary data is commonly called meta-data. This meta-data will allow researchers to understand the collected data in the detail required for their own interpretation. With the data and meta-data, the researchers can create data sets that combine data from other subtasks. As scientists interpret the data sets, the new interpreted data that they create will also go into the data repository. When the prototype testing and monitoring activities are complete, the data will be published and distributed on a CD-ROM.

\subsubsection{Data Base Strategy}

All of the subtasks will generate data for the data repository. The data from the subtasks will be validated data that has passed the subtask quality assurance guidelines (and may include calibrated raw data). Besides this validated data, some derived data (averaged or aggregated validated data) is also expected. The mean daily air temperature would be an example of averaged data that is routinely derived from hourly measurements. Data input is expected monthly from each subtask with the data described fully so that it can be defined in the IRDS. As the data arrives, it will be incorporated into the data repository.

\subsubsection{Repository for Data Base}

The data repository will consist of a central data base and one or more replica data bases. The central data base will be the master copy and will reside on a local machine with controlled access. The replica data bases will be on networked file servers or on personal computers for access by project staff. The data base administrator will be responsible for incorporating the donated data into the central data base and replicating it on the file servers. The data base administrator will also be responsible for backup, documentation, and maintenance of the data repository.

\subsubsection{Selection of Data Base}

Paradox was chosen as the relational data base management system (RDBMS) for the central data base. Paradox ${ }^{\text {Th }}$ can access data base tables on a network file server or on local drives. Considering the rapidly changing data base field, the logical design of the data base will allow for a future port to another file server RDBMS or a client server RDBMS. The physical design is based on the current version of Paradox for Windows. A Paradox-run time front-end interface will be created for accessing the data base using the development tools available with Paradox.

The primary function of the central data base interface is to ease the creation of data sets. These data sets will be exported as ASCII files that the researcher can then analyze using any analysis tool. 
The interface should provide the following features: 1) a browse feature for the viewing of data in the tables, 2) a search feature to allow the researcher to find data points of interest, 3) a help feature for access to the meta-data where the data is defined, and 4) the ability to perform custom queries and to save them for future reuse. Any owner of Paradox will have native access to the data base.

The meta-data in the IRDS should answer the following question about the data in the data base: 1) what kind of instrument collected the data? 2) what assumptions are made when creating the interpreted data? 3) what manipulations were done to the data? 4) what is the intended use or purpose of the data? 5) what techniques did the scientist use in the collection of the data? 6) what is the accuracy or quality of the data? 7) what is the source of the data, i.e., where was it collected? 8) what are the format and structure of the data? If answers to these questions are not in the IRDS, they should be in the data tables that describe the instruments and their calibrations.

\subsubsection{Data Base}

The data tables that the subtasks donate to the data repository are first normalized. Normalization is the process of simplifying the table structure. The chief advantage in normalization is the flexibility of a simpler structure. Normalized tables can adapt to changes in the data collected without changing the structure. This means that if the scientists on the project decide they need to take additional measurements; the structure doesn't need to change. Figure 3.3 shows data structures from the wind erosion subtask that were normalized using the IDEF1X information modeling technique. The wind erosion data tables were then defined in the IRDS. An initial draft report from the IRDS minimally describing preliminary wind erosion data tables is shown in the Appendix.

The sheer magnitude of the data from the prototype requires that a partitioned data base be used. Partitioning the data base is desirable because the speed and efficiency of microcomputer RDBMS degrade as the tables get larger. The data table sizes may be limited to 25,000 records or less. To achieve this, data base partitioning will be based on subtask and month. Larger data tables that store similar data will also be partitioned based on instrument location. This layout will create a family-tree structure for the physical layout of the files. To create data sets that span 2 months, the user will make addition links with the tables.

\subsubsection{Relational Scheme}

Although its primary use is for business applications, a relational system was chosen for managing this scientific data because of its availability, flexibility, programming ease, power, and cost. Unlike typical business applications, few changes to the actual data are expected because quantitative physical phenomena are typically collected at a point in time. There will probably be corrections due to errors of calibration or interpretation caught after data is donated. On the other hand, the meta-data is often qualitative and will change as necessary to provide a clearer definition of the data and collection prac- 
tices. Once the monitoring of the prototype barrier is completed and the basic interpretation of the data is finished, the data base will be published on CD-ROM for continuing analysis and use by interested parties. 


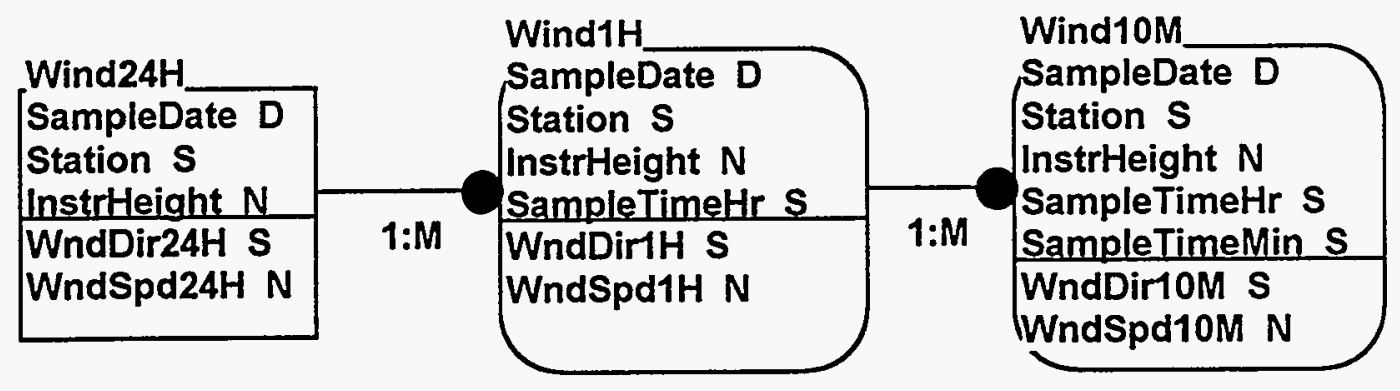

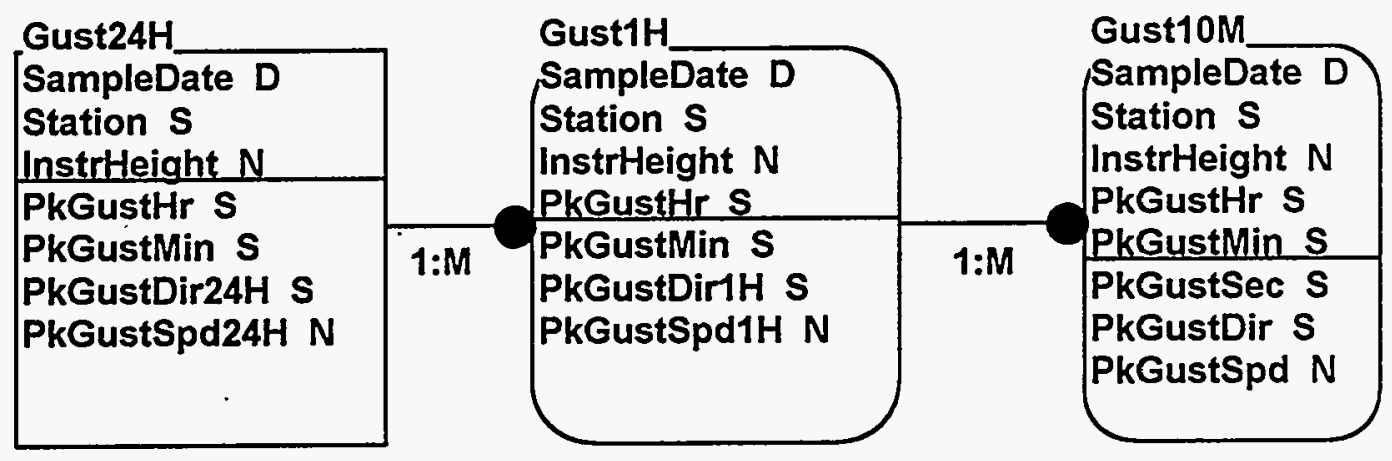

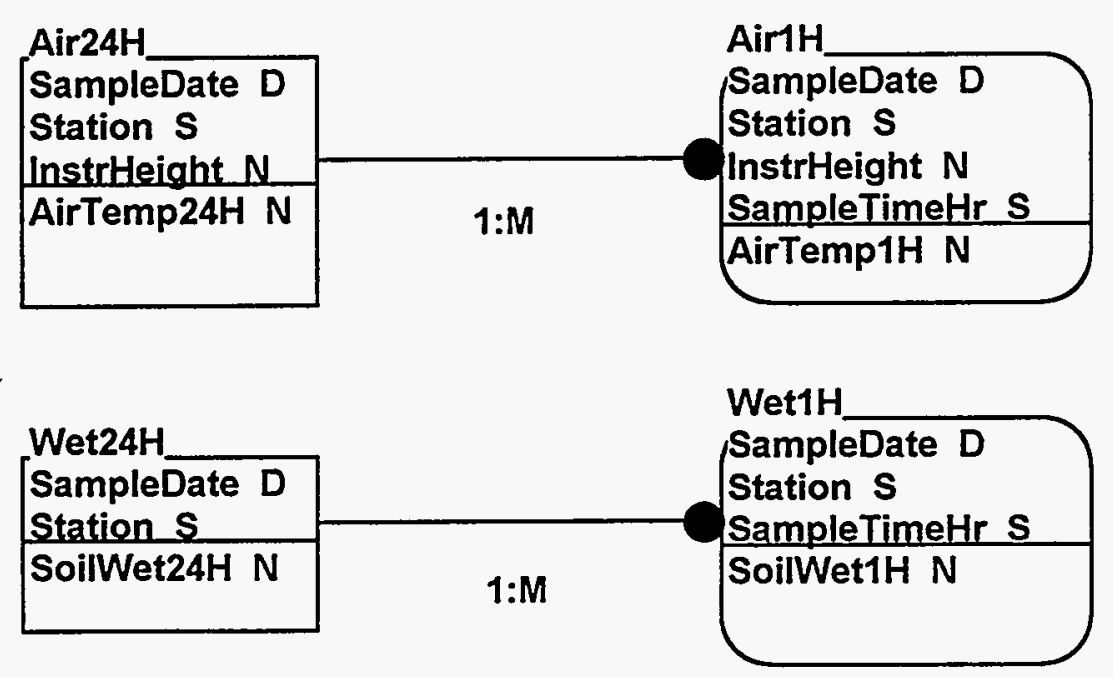

Wind Erosion ER Diagram

Figure 3.3. An Example Entity Relationship Diagram for Wind Erosion Data 


\subsection{Future Plans and Activities}

The prototype barrier will provide a unique test facility for the measurement of water balance parameters of surface barriers at the Hanford Site. The facility will allow comparison of both intrusive and nonintrusive measures of soil water content and water storage, which are both important and necessary parameters in evaluating surface barrier performance. Further, the barrier will be unique in allowing us to quantify the drainage (recharge) that will come from the soil and the side slope surfaces under ambient and elevated precipitation (extreme event) conditions. Such tests are necessary to evaluate long-term performance of surface barriers. Measures of recharge to levels of less than $0.05 \mathrm{~mm} / \mathrm{yr}$ are easily achievable with our large lysimeter system. In addition to water balance, plant intrusion, wind erosion, and water erosion features will also be quantified during the 3-year test period.

Comparisons will be made of water storage methods. Spatial variations of precipitation, soil water content, temperature, and soil suction will be evaluated at the water balance monitoring stations on the soils surface. Variations in drainage will be evaluated as a function.of water application rates and surface condition. Side slopes will be evaluated for drainage and surface stability. In addition, plant growth and survival will be documented, sediment yield will be measured, and wind erosion will be evaluated during the 3-year study.

One of the major contributions of water balance testing will be in providing quality data (e.g., precipitation, water storage, drainage, runoff, etc.) used in testing hydrologic models of surface water balance. Such modeling is critical to DOE in providing estimates of long-term performance of surface barriers at the Hanford Site. Barrier performance will be judged by estimated drainage rates and projections of long-term recharge. These projections will require computer models that are calibrated for Hanford Site conditions. The prototype barrier data set will be the only data set of its kind in the country available for model validation. The uniqueness of such a data set cannot be overemphasized. As the data is collected and carefully analyzed, it will be made available for site-wide use. The data set could likely become a standard set by which surface water balance models for other arid sites are compared and tested.

Additional work is needed to extend the usefulness of the prototype beyond the three-year test period and to capture the full value of this new facility on testing surface barrier concepts at the Hanford Site. To accomplish this, the following activities are recommended:

- Maintenance of the Field Lysimeter Test Facility (FLTF). The FLTF has been renovated and includes six large lysimeters that contain prototype barrier materials. Tests conducted at the FLTF over the next 3 years will complement and extend the prototype barrier tests by allowing controlled measurements of drainage from side slope and surface materials that are subjected to normal and extreme precipitation events. 
- Comparison of the Hanford Barrier to other barrier systems. Work to test a prototype Hanford barrier analog under elevated natural precipitation was initiated at the Hill Air Force Base (HAFB) in'Ogden, Utah, in 1994 (Kirkham and Gee 1994). Prototype barrier materials from the Hanford Site are being tested in a large $(5 \times 10 \times 2.5 \mathrm{~m})$ lysimeter in a side-by-side comparison with four other cover systems, including a RCRA cover containing a buried clay layer. The climate at HAFB represents a three-fold increase in precipitation over normal climate at the Hanford Site. The response of the prototype analog to increased precipitation stress will be monitored with time over the next several years valuable performance data for HAFB will be obtained to provide support for the Hanford Site barrier designs. Testing and monitoring funds are needed to continue this work.

- Model verification work. Acceptance of long-term performance of barriers rely heavily on computer simulations. Selected surface barrier designs are compared and their expected performance evaluated using appropriate computer models. However, computer models require verification and steps must be taken to ensure predictions are close to reality and within acceptable limits. While simulations of lysimeter (one-dimensional) water balance has been successful, no simulation model of a full-scale barrier system has been verified for the Hanford Site. Plans to complete model verification work are currently delayed because of funding limitations. This delay may compromise completing final designs for surface barriers proposed for the Hanford Site. Modeling efforts coupled with prototype data should provide necessary verification tests to support acceptance of waste disposal alternatives that include surface covers.

- Asphalt technology support. Work on asphalt testing, including tests for permeability, physical stability, longevity, and durability should continue. Such information is needed to provide support for use of asphalt as an acceptable barrier component.

- Technology transfer activities. The interchange and transfer of barrier technology information from the Hanford Barrier Development Team to end-users onsite and throughout the DOE complex should continue. Workshops and symposia to facilitate this exchange should be funded. 


\subsection{References}

Du, S., and P. Rummel. 1994. "Reconnaissance Studies of Moisture in the Subsurface with GPR." Proceedings of the Fifth International Conference on Ground Penetrating Radar, June 12-16, 1994, Kithchener, Ontario, Canada.

Gee, G. W., L. L. Cadwell, H. D. Freeman, M. W. Ligotke, S. O. Link, R. A. Romine, and W. H. Walters, Jr. 1993. Testing and Monitoring Plan for the Permanent Isolation Surface Barrier Prototype. PNL-8391, Pacific Northwest Laboratory, Richland, Washington.

Hook, W. R., N. J. Livingston, Z. J. Sun, and P. B. Hook. 1992. "Remote Diode Shorting Improves Measurement of Soil Water by Time Domain Reflectometry." Soil Sci. Soc. Am. J. 56: 1384-1391.

Kachanoski, R. G., E. G. Gregorich, and I. J. Van Wesenbeeck. 1988. "Estimating Spatial Variations in Soil Water Content Using Noncontacting Electromagnetic Inductive Methods." Can. J. Soil Sci. 68:715-722.

Kaiser Engineers Hanford (KEH). 1993. Engineering Report Prototype Surface Barrier at 200-BP-1 Operable Unit. WHC-SD-EN-TI-142. Rev. 0., Westinghouse Hanford Company, Richland, Washington.

Kirkham, R. R., and G. W. Gee. 1994. Experimental Plan and Construction Guidance for Hanford Protective Barrier Test at Hill AFB, Ogden, Utah. PNL-9412, Pacific Northwest Laboratory, Richland, Washington.

Ligotke, M. W., and D. C. Klopfer. 1990. Soil Erosion Rates from Mixed Soil and Gravel Surfaces in a Wind Tunnel. PNL-7435, Pacific Northwest Laboratory, Richland, Washington.

Ligotke, M. W. 1993. Soil Erosion Rates Caused by Wind and Saltating Sand Stresses in a Wind Tunnel. PNL-8478, Pacific Northwest Laboratory, Richland, Washington.

Link, S. O., L. L. Cadwell, C. A. Brandt, J. L. Downs, R. E. Rossi, G. W. Gee. 1994. Biointrusion Test Plan For The Permanent Isolation Surface Barrier Prototype. PNL-9411, Pacific Northwest Laboratory, Richland, Washington.

Myers, D. R., and D. A. Duranceau. 1994. Prototype Hanford Surface Barrier: Design Basis Document. BHI-00007, Bechtel Hanford Inc., Richland, Washington.

Topp, G. C., J. L. Davis, and A. P. Annan. 1980. "Electromagnetic Determination of Soil Water Content: Measurement in Coaxial Transmission Lines". Water Resour. Res. 16:574-582. 
U.S. Department of Energy (DOE). 1994. Constructability Report for the 200-BP-1 Prototype Surface Barrier. DOE/RL-94-76. U.S. Department of Energy, Richland, Washington.

Wing, N. R. 1994. Permanent Isolation Surface Barrier Development Plan. WHC-EP-0673, Westinghouse Hanford Company, Richland, Washington.

Wing, N. R., and G. W. Gee. 1994. "Quest for the Perfect Cap." Civil Engineering 64(10):38-41. 


\section{Appendix A}

Water Balance Equipment at the Prototype Site 


\section{Appendix A}

\section{Water Balance Equipment at the Prototype Site}

\section{A.1 Water Balance Equipment and Vendors}

Petty Irrigation

Toppenish, WA 99352

2. Snow Machine

Ratnic Industries

670 Phillips Rd

Victor, NY 14564

3. Neutron Probe

CPN Corporation

Model 503 DR

2830 Howe Road

Hydroprobe

Martinez, CA 94553

4. Capacitance Probe

Sentry 200-AP

Troxler Electronic Lab., Inc.

P.O. Box 12057

Research Triangle Park, NC

26609

5. TDR Probe System

Environmental Sensors

MP-917 DM Meter, Custom-built SD Probes

(M/N 1/15:2/15:3/15:4/15

4/40:5/50:6/35:7:14)

6. TDR System Multiplexers

100-4234 Glanford Ave.

Victoria, BC V8Z 4B9

Canada

Campbell Scientific, Inc.

815 W. 1800 N.

P.O. Box 551

Logan, UT 84321

7. Soil Suction Sensors

Model 229L

Heat Dissipation Units

Campbell Scientific, Inc.

815 W. 1800 N.

P.O. Box 551

Logan, UT 84321 
8. Soil Suction Sensors MC-314 Soil Moisture Cells (Fiberglass Blocks)

9.

Mini-Lysimeters

Model 6762 Load Cells
ELE International, Inc.

Soil Test Products Division

86 Albrecht Dr.

Lake Bluff, II 6004

Revere Transducers

14020 Balboa Lane

Cerrittos, CA 90701

\section{A.2 Irrigation and Snow Machine Descriptions}

The irrigation and snow machines were custom designed for the prototype barrier testing. Details on the specifications and features of these units are provided in the following sections.

\section{A.2.1 General Information}

Water and power will be available at the prototype barrier in early FY 1995. The water supply is from a $7.6 \mathrm{~cm}$ ( $3 \mathrm{in}$.) high density polyethylene (HDPE) supply line at 125 psi with 75 psi. The electric power is $480 \mathrm{~V}$, three phase, supplying up to 67 horsepower, with a $220 \mathrm{~V}$, single phase, 50 amp panel and a $110 \mathrm{~V}, 30$ amp panel for instrumentation.

\section{A.2.2 Irrigation System Requirements}

The irrigation system will apply water uniformly to the north half of the prototype plot as shown in Figure 2.2. The irrigation system is designed to move back and forth on the north slope roadway and does not touch the test area except on the roadway. The linear move sprinkler system spans $43.6 \mathrm{~m}$ (143 ft) and delivers water only to areas within the road perimenter. The irrigation system also provides $10.4 \mathrm{~m}(34 \mathrm{ft})$ extension booms beyond the wheels to irrigate the edges of the plot when desired. The main drive wheels travel north and south along the west roadway.

The irrigation system travel speed is a maximum of $1.8 \mathrm{~m}(6 \mathrm{ft})$ per minute. Between roadways,

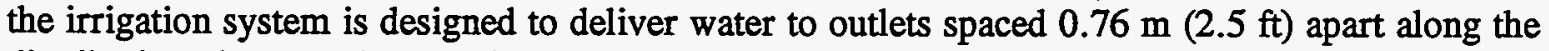
distribution pipe. Each outlet is equipped with a $1.9 \mathrm{~cm}(0.75 \mathrm{in}$.) ball valve, a rocker arm lever and drop cords, a pressure regulator, a metal U-tube, a drop tube that reaches within $0.91 \mathrm{~m}(3 \mathrm{ft})$ of the soil surface, to which a Wobbler nozzle is attached. The irrigation system is capable of gravity drainage at the roadways at both ends.

\section{A.2.3 Irrigation System Component}

The Lockwood linear move irrigation system comprises the following items:

1. Two A-frames, each with two wheels equipped with traction rubber tires.

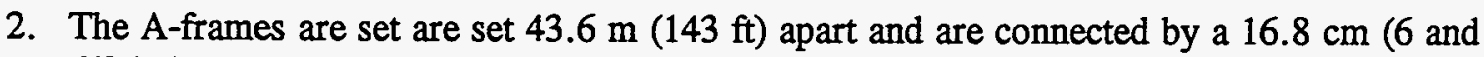
$5 / 8$ in.) water supply pipe suspended on a bow-truss rigging.

3. Two end booms, each extending $10.7 \mathrm{~m}$ (35 ft) outboard from the A-frames. 
4. Eighty-five drop tubes at $0.76 \mathrm{~m}(2.5 \mathrm{ft})$ intervals that descend from the water supply pipe to Wobbler nozzles mounted about $0.9 \mathrm{~m}(3 \mathrm{ft})$ above the soil surface.

5. Each nozzle is fitted with a 90 -degree ball valve and a $74 \mathrm{kPa}(20 \mathrm{psi})$ regulator to control water flow.

\section{A.2.4 Snow Machine Requirements}

Snow will be applied over the course of the winter. A total of three winter applications will be made from December through January. The first two applications rates will be equivalent to approximately $11.2 \mathrm{~mm}$ of water. The third application will be similar in amount if needed and will be used to ensure that a total of $33.5 \mathrm{~mm}$ of water is applied in the form of snow. Snow applications should be in 4-hour intervals. Average temperature during the application should be below $-4^{\circ} \mathrm{C}$ $\left(26^{\circ} \mathrm{F}\right)$. The average relative humidity range should be from 75 to $84 \%$. Average nonsnow wind conditions expected would be from the northwest at $3.5 \mathrm{~m} / \mathrm{s}(7 \mathrm{mph})$ and should not exceed $5 \mathrm{~m} / \mathrm{s}$ (10 mph) during snow application. A minimum of two people will be needed to operate the equipment during snow applications.

\section{A.2.5 Snow Machine Equipment}

The snow machine consists of the following equipment:

1. One Sulair rotary compressor driven by a $60 \mathrm{hp}, 480 \mathrm{~V}$, three phase motor.

2. Two custom made snow guns on towers.

3. Eight $3.8 \mathrm{~cm}(1.5 \mathrm{in})$ dia. by $30.4 \mathrm{~m}$ (100 ft) hoses, for snow delivery.

4. One low-pressure emergency shut-down valve.

5. Two reverse-flow restriction valves.

6. One water flow meter.

7. Two ball valves and two gate valves for flow control.

8. Air and water piping.

9. One twin-axle trailer, with ball hitch and light system.

\section{A.2.6 Snow Machine Water Disposal}

Emergency low-pressure water shut-off near the water hydrant and remote drainage of the system are provided to avoid water damage to the equipment or the test plot area by gravity flow and in a nonerosive manner.

\section{A.2.7 Snow Application Constraints}

A single snow application should contain not more than $25 \mathrm{~mm}$ of water. Snow should be applied when the ground is frozen or when there is natural snow cover and when the air temperature is below $0^{\circ} \mathrm{C}\left(32^{\circ} \mathrm{F}\right)$. Snowmaking equipment should operate only from the west roadway. Water delivery and time should be recorded for each application. Equipment mobilization requires the use of the twin-axle trailer. 


\section{Distribution}

No. of

Copies

\section{OFFSITE}

12 DOE/Office of Scientific and Technical Information

C. S. Abrams

Argonne National Laboratory

P.O. Box 2528

Idaho Falls, ID 83401

2 Battelle Memorial Institute

Project Management Division

505 King Avenue

Columbus, $\mathrm{OH} 43201$

ATTN: W. A. Carbeiner. Technical Library

\section{Benge}

Bechtel-FUSRAP

P.O. Box 350

Oak Ridge, TN 37830

R. D. Bennett

U.S. Army Engineer Waterways

Experiment Station

3909 Halls Ferry Road

Vicksburg, MS 39180-6199

B. Bede

U.S. Ecology

509 E. 12th

Olympia, WA 98501

R. R. Borish

West Valley Nuclear Service

Company

P.O. Box 191

West Valley, NY 14171
No. of

Copies

Chem Nuclear Geotech

P.O. Box 14000

Grand Junction, CO 81502

ATTN: W. J. Waugh

A. T. Clark

U.S. Nuclear Regulatory

Commission

Division of Fuel Material Safety

Washington, D.C. 20555

D. E. Daniel

University of Texas

Department of Civil Engineering

Austin, TX 78712

Desert Research Institute

P.O. Box 60220

Reno, NV 89506

ATTN: S. W. Tyler

M. Dunkelman

Department of Health

Division of Radiation

Protection

Airdustrial Park

Bldg. 5, MS LE-13

Olympia, WA 98504

2. Foster-Wheeler

Environmental Corp.

1981 Snyder Rd

Suite 3

Richland, WA 99352

ATTN: W. Riggsbee

R. L. Treat

Distr.1 
No. of

Copies

3 Environmental Protection Agency

Hanford Project Office

712 Swift, MS B5-01

Richland, WA 99352

ATTN: P. R. Beaver

D. A. Faulk

P. S. Innis

\section{S. Evans}

U.S. Department of Energy

1580 Sawtelle Drive

Idaho Falls, ID 83403

L. G. Everett

Geraghty \& Miller, Inc.

5425 Hollister Ave., Suite 100

Santa Barbara, CA 93111-2346.

F. T. Fong

U.S. Department of Energy

San Francisco Operations

Office

1333 Broadway

Oakland, CA 94612

2 Hill Air Force Base

Environmental Management

Directorate

OO-ALC/EM

7276 Wardleigh Road

Hill AFB, UT 84056-5127

ATTN: B. Elliot

D. Stone

R. G. Hills

Department of Mechanical Eng.

New Mexico State University

Box 30001

La Cruces, NM 88003
No. of

Copies

7 Idaho National Engineering

Laboratory

P.O. Box 1625

Idaho Falls, ID 83415

ATTN: J. E. Conner

J. Hubbell

M. A. Knecht

K. M. Kostelnik

D. L. McElroy

J. B. Sisson

Technical Library

4 Jacobs Engineering Group, Inc.

2155 Louisiana Blvd. NE

$\# 1000$

Albuquerque, NM 87110-5414

ATTN: M. Kyllo
J. Lommler
F. Titus
T. Goering

M. R. Jugan

U.S. Department of Energy

Oak Ridge Operations Office

P.O. Box E

Oak Ridge, TN 37830

W. A. Jury

University of California

at Riverside

Department of Soils

Riverside, CA 92502

D. Keefer

Illinois State Geological

Survey

615 East Peabody Drive

Champaign, IL 61820

C. Keller

SNL, Eastman Cherrington

P.O. Box 10129

Santa Fe, NM 87504 
No. of

Copies

D. A. Knecht

Westinghouse Idaho Nuclear Co.

P.O. Box 4000

Idaho Falls, ID 83403

R. C. Letcher

U.S. Department of Energy

Morgantown Energy Technology

Center

P.O. Box 880

Morgantown, WV 26505

4 Los Alamos National Laboratory

P.O. Box 1663

Los Alamos, NM 87545

ATTN: F. Barnes

K. V. Bostick

J. W. Nyhan

E. Springer

E. Maestas

U.S. Department of Energy

West Valley Project Office

P.O. Box 191

West Valley, NY 14171

C. Mascarenas

WINCO

P.O. Box 4000, MS 1572

Idaho Falls, ID 83404

C. Massimino

U.S. Environmental Protection

Agency

1200 Sixth Avenue

Seattle, WA 98101

S. Needler

EG\&G, Rock Flats

P.O. Box 464, Building 080

Golden, CO 80402
No. of

Copies

$4 \quad$ Oak Ridge National Laboratory

P.O. Box 2008

Oak Ridge, TN 37831

ATTN: J. Kuhaida

R. J. Luxmoore

M. Marietta

G. Suter II

2 Oak Ridge National Laboratory

P.O. Box Y

Oak Ridge, TN 37830

ATTN: W. D. Burch

R. T. Jubin

D. T. Oakley

Waste Policy Institute

555 Quince Orchard Road

Suite 600

Gaithersburg, MD 20878

Ginger Paige

USDA-ARS

Tucson AZ 85715

C. Reith

Dyn McDermott Petroleum

Services

850 South Clearview Parkway

New Orleans, LA 70123

J. Rensel, MS PV-11

Washington State Department

of Ecology

High-Level Waste Management

Olympia, WA 98504

G. N. Richardson

Hazen and Sawyer

4011 W: Chase Blvd.

Suite 500

Raleigh, NC 27607 
No. of

Copies

2 Sandia National Laboratories

P.O. Box 5800

Albuquerque, NM 87185

ATTN: R. W. Lunch

Technical Library

Dr. B. Scanlon

Bureau of Economic Geology

University of Texas

University Station Box X

Austin, TX 78713-7508

J. A. Shaffner

U.S. Ecology

3855 Atherton Road

Suite 5

Rocklin, CA 95765

R. Shaw

Electric Power Research

Institute

3412 Hillview Avenue

Palo Alto, CA 94304

W. G. Spaulding

Dames and Moore

Suite 108

4220 S. Maryland Parkway

Las Vegas, NV 89119

M. J. Steindler

Argonne National Laboratory 9700 South Cass Avenue

Argonne, IL 60439

J. B. Stong

Gonzaga University

Civil Engineering Department

E. 502 Boone

Spokane, WA 99258-0001
No. of

Copies

$2 \quad$ U.S. Department of Energy-

Albuquerque Operations Office

P.O. Box 5400, MS ERPO

Albuquerque, NM 87185-5400

ATTN: K. Bitner

G. J. Rael

3 U.S. Department of Energy

785 DOE Place

Idaho Falls, ID 83402

ATTN: O. D. Markham

R. C. Morris

T. E. Reynolds

2 U.S. Department of Energy

Savannah River Operations

Office

P.O. Box A

Aiken, SC 29801

ATTN: W. J. Brumley

D. Bruegennjohann

2 U.S. Ecology

5333 Westheimer

Suite 1000

Houston, TX 77056-5407

ATTN: A. Palmer

L. D. Irwin

2 U.S. Geological Survey

$333 \mathrm{~W}$. Nye Lane

Carson City, NV 89706

ATTN: B. J. Andraski

D. E. Prudic

2 U.S. Geological Survey

Low-Level Radioactive Waste

Program

Water Resources Division 12201 Sunrise Valley Drive

Reston, VA 22092

ATTN: N. Trask

I. Winograd 
No. of

Copies

2 U.S. Geological Survey

1201 Pacific Ave., Suite 600

Tacoma, WA 98402

ATTN: W. R. Bidlake

W. Staubitz

2 U.S. Nuclear Regulatory

Commission

Division of Engineering Safety

Waste Management Branch

5650 Nicholson Lane

Rockville, MD 29852

ATTN: T. J. Nicholson

E. O'Donnell

Washington State Department of Ecology

1315 W. 14th Ave.

Kennewick, WA 99336

ATTN: N. Uziemblo

3 Washington State Department of Ecology

MS PV-11

Olympia, WA 98504-8711

ATTN: E. M. Carlin

C. Cline

R. B. Hibbard

6 Washington State University

Geology Department

Pullman, WA 99164

ATTN: A. J. Busacca

G. S. Campbell

D. Gaylord

K. Keller

L. G. King

P. J. Mehringer

M. Weishan

NYSERDA

P.O. Box 191

West Valley, NY 14171
No. of

- Copies

10 Westinghouse Savannah River

Company

P.O. Box 616

Aiken, SC 29802

ATTN: J. Cook

M. Flora

L. Huber

J. R. Knight

S. R. McMullin

E. Norton

M. J. Plodinec

C. T. Randall

E. Schiefer

M. G. Serrato

P. J. Wierenga

University of Arizona

Department of Soil \& Water

429 Shantz Building

Tucson, AZ 85721

\section{FOREIGN}

M. Barrès

BRGM - Department

"Environment"

BP 6009

45060 ORLEANS CEDEX, FRANCE

P. Grimwood

Waste Management Unit

British Nuclear Fuels plc

Sellafield

Seascale, Cumbria CA201PG

ENGLAND

S. Melchior

Institut für Bodenkunde der

Universität Hamburg

Allende-Platz 2, D-2000

Hamburg 13

FEDERAL REPUBLIC OF GERMANY 
No. of

Copies

G. M. Smith

Intera Information Technologies

Chiltern House

45 Station Road

Henley-on-Thames

Oxfordshire RG9 1AT

UNITED KINGDOM

\section{ONSITE}

13 DOE Richland Operations Office

J. J. Broderick

A7-27

B. L Foley

H4-83

R. D. Freeberg

H4-83

R. E. Gerton

S7-54

J. D. Goodenough

$\mathrm{H} 4-83$

J. P. Hanson

K8-50

R. D. Izatt

P. M. Pak

A7-50

R. K. Stewart

H4-83

H4-83

D. E. Trader

K8-50

S. L. Trine

S7-53

S7-53

W. R. Wrzesinski

A1-65

$2 \quad$ U.S. Army Corps of Engineers

W. L. Greenwald

A5-20

J. H. Jacobson

A3-61

5 Kaiser Engineers Hanford Company
S. D. Consort
E6-46
D. L. Fort
E6-25
L. A. Gladdis
G7-57
W. E. Hamilton
L6-79
R. I. Watkins
E6-41

23 Westinghouse Hanford Company
M. R. Adams
H6-30
H. Babad
S7-30
R. J. Bliss
B3-04
W. F. Heine
B3-63

No. of

Copies
H6-33

K. N. Jordan S7-83

W. J. Karwoski H6-30

R. E. Lerch \$7-85

H. E. McGuire B3-63

D. E. McKenney N3-10

D. J. Newland R3-12

R. W. Powell H4-14

R. C. Roos H6-30

W. A. Skelly H6-30

J. C. Sonnichsen H6-06

J. A. Voogd R4-01

G. F. Williamson R4-01

D. D. (Don) Wodrich $57-84$

R. D. Wojtasek S7-84

D. E. Wood H6-30

Central Files L8-04

ER Program Information

Center (2) H6-08

32 Pacific Northwest Laboratory

L. L. Cadwell K6-63

R. S. Davis K9-33

J. L. Downs K6-63

M. J. Fayer K9-33

D. Felmy K9-33

H. D. Freeman P8-38

G. W. Gee K9-33

C. T. Kincaid K9-33

R. R. Kirkham K9-33

G. V. Last K9-48

M. W. Ligotke P7-59

S. O. Link K6-63

W. S. Madia K1-46

T. L. Page K9-18

K. L. Peterson K6-60

J. C. Ritter K9-33

M. L. Rockhold K9-33

L. E. Rogers K6-63

R. A. Romine P8-38

M. R. Sackschewsky K6-63

M. A. Simmons K6-63

R. L. Skaggs K9-34 
No. of

Copies

M. E. Thiede

K6-52

J. M. Thomas

K6-63

W. H. Walters

K9-33

Publishing Coordination

Technical Report Files (5)

Hanford Technical Library

P8-55
No. of

Copies

Routing

$\begin{array}{ll}\text { R. M. Ecker } & \text { Sequim } \\ \text { M. J. Graham } & \text { K9-38 } \\ \text { P. M. Irving } & \text { K9-05 } \\ \text { S. A. Rawson } & \text { K9-34 } \\ \text { P. C. Hays (last) } & \text { K9-41 }\end{array}$

33 Bechtel Hanford, Inc.

M. A. Buckmaster H6-01

R. A. Carlson H6-01

C. C. Chamberlain H6-28

G. R. Chiaramonte H6-01

A. P. Church H6-01

F. M. Corpuz H4-85

T. A. Curran B2-68

J. Darby H4-84

H. D. Downey H4-84

V. R. Dronen H4-82

D. A. Duranceau H4-14

K. R. Fecht H4-85

H. K. Forsen H6-02

A. Freitag . H4-79

M. C. Hagood H6-02

C. E. Hodge H4-82

R. W. Hookfin H6-02

A. Hopkins $\quad$ H4-79

C. J. Kemp H4-14

D. S. Landeen H4-14

M. J. Lauterbach H6-01

S. D. Liedle H4-84

D. R. Myers H4-14

W. C. Shafer, Jr. H4-82

D. Teel H4-86

J. S. Treadwell H4-79

S. R. Weil H4-86

N. R. Wing H4-14

T. M. Wintczak H4-81

J. G. Woolard H6-01

J. G. Zoghbi H6-07

Document Control H4-79

Environmental Resources

Center

H6-07 